\title{
Influence of fuel ethanol content on primary emissions and secondary aerosol formation potential for a modern flex-fuel gasoline vehicle
}

\author{
Hilkka Timonen $^{1}$, Panu Karjalainen ${ }^{2}$, Erkka Saukko $^{2, a}$, Sanna Saarikoski ${ }^{1}$, Päivi Aakko-Saksa ${ }^{3}$, Pauli Simonen ${ }^{2}$, \\ Timo Murtonen ${ }^{3}$, Miikka Dal Maso ${ }^{2}$, Heino Kuuluvainen ${ }^{2}$, Matthew Bloss ${ }^{1}$, Erik Ahlberg ${ }^{4,5}$, Birgitta Svenningsson ${ }^{5}$, \\ Joakim Pagels ${ }^{6}$, William H. Brune ${ }^{7}$, Jorma Keskinen ${ }^{2}$, Douglas R. Worsnop ${ }^{8}$, Risto Hillamo ${ }^{1}$, and Topi Rönkkö̈ ${ }^{2}$ \\ ${ }^{1}$ Finnish Meteorological Institute, Atmospheric Composition Research, P.O. Box 503, 00101 Helsinki, Finland \\ ${ }^{2}$ Tampere University of Technology, Faculty of Natural Sciences, Aerosol Physics, P.O. Box 692, 33101 Tampere, Finland \\ ${ }^{3}$ VTT Technical Research Centre of Finland, P.O. Box 1000, 02044 VTT Espoo, Finland \\ ${ }^{4}$ Centre for Environmental and Climate Research, Lund University, Box 118, 22100 Lund, Sweden \\ ${ }^{5}$ Division of Nuclear Physics, Lund University, Box 118, 22100 Lund, Sweden \\ ${ }^{6}$ Division of Ergonomics and Aerosol Technology, Lund University, Box 118, 22100, Lund, Sweden \\ ${ }^{7}$ Department of Meteorology, Pennsylvania State University, University Park, PA, USA \\ ${ }^{8}$ Aerodyne Research Inc., Billerica, MA, USA \\ a currently at: Pegasor Oy, Hatanpään valtatie 34C, 33100 Tampere, Finland
}

Correspondence to: Hilkka Timonen (hilkka.timonen@fmi.fi)

Received: 4 July 2016 - Discussion started: 26 September 2016

Revised: 8 March 2017 - Accepted: 24 March 2017 - Published: 24 April 2017

\begin{abstract}
The effect of fuel ethanol content (10, 85 and $100 \%$ ) on primary emissions and on subsequent secondary aerosol formation was investigated for a Euro 5 flex-fuel gasoline vehicle. Emissions were characterized during a New European Driving Cycle (NEDC) using a comprehensive setup of high time-resolution instruments. A detailed chemical composition of the exhaust particulate matter (PM) was studied using a soot particle aerosol mass spectrometer (SPAMS), and secondary aerosol formation was studied using a potential aerosol mass (PAM) chamber. For the primary gaseous compounds, an increase in total hydrocarbon emissions and a decrease in aromatic BTEX (benzene, toluene, ethylbenzene and xylenes) compounds was observed when the amount of ethanol in the fuel increased. In regard to particles, the largest primary particulate matter concentrations and potential for secondary particle formation was measured for the E10 fuel (10\% ethanol). As the ethanol content of the fuel increased, a significant decrease in the average primary particulate matter concentrations over the NEDC was found. The PM emissions were $0.45,0.25$ and $0.15 \mathrm{mg} \mathrm{m}^{-3}$ for E10, E85 and E100, respectively. Similarly, a clear decrease in
\end{abstract}

secondary aerosol formation potential was observed with a larger contribution of ethanol in the fuel. The secondary-toprimary PM ratios were 13.4 and 1.5 for E10 and E85, respectively. For E100, a slight decrease in PM mass was observed after the PAM chamber, indicating that the PM produced by secondary aerosol formation was less than the PM lost through wall losses or the degradation of the primary organic aerosol (POA) in the chamber. For all fuel blends, the formed secondary aerosol consisted mostly of organic compounds. For E10, the contribution of organic compounds containing oxygen increased from $35 \%$, measured for primary organics, to $62 \%$ after the PAM chamber. For E85, the contribution of organic compounds containing oxygen increased from $42 \%$ (primary) to $57 \%$ (after the PAM chamber), whereas for E100 the amount of oxidized organics remained the same (approximately $62 \%$ ) with the PAM chamber when compared to the primary emissions. 


\section{Introduction}

Vehicular engine emissions are known to degrade air quality in urban areas. Besides gaseous compounds (e.g. CO, $\mathrm{NO}_{x}$, hydrocarbons and volatile organic compounds), vehicle exhaust contains significant amounts of primary particulate matter (PM) (e.g. Maricq, 2007; Keuken et al., 2013; Gordon et al., 2014a). Primary particulate matter refers to particles directly emitted from the engine, the fuel combustion process or the brakes that have not yet experienced any significant chemical transformation in the atmosphere. Depending on the engine and fuel type, primary exhaust PM emissions from vehicles consist mainly of soot and different fuel and lubricating oil components (Maricq, 2007; Canagaratna et al., 2010; Karjalainen et al., 2014). In addition to primary PM, burning processes in engine cylinders produce so-called delayed primary aerosol. Delayed primary aerosol includes species like sulfuric acid which occur in tailpipe conditions in a gaseous phase but will condense or nucleate immediately when the exhaust is cooled and diluted without any significant chemical transformation in the atmosphere (Arnold et al., 2012; Rönkkö et al., 2013; Pirjola et al., 2015). In particle number size distribution, the exhaust PM formed by these different processes is frequently seen in separate modes with different concentrations and particle size ranges (Kittelson, 1998; Rönkkö et al., 2013). In addition to primary emissions, large amounts of secondary particulate matter form after the exhaust gases are released into the atmosphere (Chirico et al., 2010). Secondary particulate matter forms in the atmosphere via gas-to-particle conversion as oxidation processes typically lower the volatility (vapour pressure) of gaseous compounds. The difference between delayed primary and secondary emissions is that secondary emissions form through different transformation processes in the atmosphere, whereas delayed primary emissions form in the cooling process without any significant chemical transformation due to external conditions such as ultraviolet light (UV) or atmospheric oxidants. While a large number of studies have focused on vehicular primary particulate emissions (Giechaskiel et al., 2005; Maricq, 2007; Lähde et al., 2010; Karjalainen et al., 2014), a relatively limited number of studies have focused on secondary emissions.

Both batch chambers (such as smog chambers) and flowthrough chambers combined with modern online composition analysis (e.g. AMS) have been used to study vehicular secondary aerosol emissions in both laboratory and ambient conditions. Smog chambers have been used to study the composition of the primary and secondary PM in the exhaust emissions of gasoline and diesel vehicles, the influence of after-treatment on secondary aerosol formation for diesel vehicles, the fraction of the emissions that forms secondary organic aerosol (SOA) and the relative importance of primary PM emissions versus SOA formation (e.g. Nordin et al., 2013; Platt et al., 2013; Chirico et al., 2014; Gordon et al., 2014a; Presto et al., 2014). A batch chamber is good for detailed oxidation process studies (e.g. Chirico et al., 2014; Suarez-Bertoa et al., 2015), but cannot be used to differentiate the rapidly changing driving conditions during the test driving cycle. Flow-through chambers, such as the potential aerosol mass (PAM) chamber, are designed to simulate secondary aerosol mass formation potential on a nearly real-time basis (Kang et al., 2011; Lambe et al., 2011). Several studies have been recently published for which the PAM chamber was used to study the vehicular emissions from gasoline, diesel and flex-fuel vehicles (e.g. Kroll et al., 2012; Suarez-Bertoa et al., 2015; Karjalainen et al., 2016; Jathar et al., 2017). These studies have shown that secondary particulate emissions from combustion engines mainly consist of organic compounds and ammonium nitrate (Karjalainen et al., 2016; Suarez-Bertoa et al., 2015) and that the secondary PM emissions can be significantly larger than the primary emissions if the conditions favour secondary aerosol formation (Giechaskiel et al., 2005; Chirico et al., 2010; Karjalainen et al., 2016). In gasoline vehicles, the exhaust emissions of secondary aerosol precursors have been shown to depend on driving conditions, fuels and the operation of catalytic converters (Durbin et al., 2007; Maricq et al., 2012; Gordon et al., 2014b; Karjalainen et al., 2016). Also, previous studies indicate that gasoline vehicles have an impact on secondary aerosol concentrations in urban areas (Nordin et al., 2013; Tkacik et al., 2014; Karjalainen et al., 2016; Suarez-Bertoa et al., 2015). However, the secondary aerosol formation potential and the composition as a function of the driving situation for fuels with different ethanol contents (E10-E100) remain poorly characterized in the literature.

The hydrocarbons of gasoline typically include 4-12 carbon atoms with a boiling range between 30 and $210^{\circ} \mathrm{C}$ (Owen and Coley, 1995). These may be present in the exhaust gases as unburned hydrocarbons. In addition, exhaust gases contain compounds formed in combustion and originating from engine oil. Lipari (1990) analyzed 103 individual hydrocarbons up to $\mathrm{C}_{12}$ in a study with flex-fuel vehicles (FFVs) using the gasoline- and methanol-containing fuels M85 and M100 (85 and $100 \%$ methanol). Toluene, ethylene, propylene, isobutylene, isopentane, pentane, benzene and iso-octane represented $55 \%$ of the total hydrocarbons for gasoline. These gaseous compounds are emitted into the atmosphere directly, or they are evaporated from primary exhaust particles when the exhaust is diluted (Robinson et al., 2007). The oxidation products of organic compounds may contain one or more functional groups, such as alcohol ($\mathrm{OH})$, aldehyde (-CHO), carboxylic acid (- $\mathrm{COOH})$, nitro ($\left.\mathrm{NO}_{2}\right)$ and nitrate $\left(-\mathrm{NO}_{3}\right)$ or organic sulfate $\left(-\mathrm{OSO}_{3}\right)$. Ambient photochemical reactions take place in the presence of $\mathrm{NO}_{2}$, volatile organic compounds (VOCs), heat and sunlight. Hundreds of different VOC species can participate in thousands of photochemical reactions (Drechsler et al., 2004). The different possible photo-oxidation pathways are also dependent on the conditions. Aromatic BTEX (BTEX; benzene, toluene, ethylbenzene and xylenes; the VOCs typically 
found in petroleum derivates) compounds have been suggested to depend on, for example, the prevailing $\mathrm{NO}_{x}$ concentrations during the aging process (Andino et al., 1996; Hurley et al., 2001; Sato et al., 2007, 2012).

The European Union has set an obligation that the share of renewable energy should be at least $10 \%$ in the transportation sector by 2020 (Directive 2009/28/EC). Ethanol is the dominant bio-component in transport fuels worldwide. However, in Europe its share in gasoline is limited to $10 \%$ vol, which is equivalent to approximately $6 \%$ energy content (Directive 2009/30/EC). Higher ethanol concentrations up to $85 \%$ vol (E85) can be used in special flex-fuel vehicles. Previous studies have shown that primary $\mathrm{PM}, \mathrm{CO}, \mathrm{HC}, \mathrm{NO}_{x}$ and aromatic hydrocarbon emissions are typically lower for the E85 fuel than for gasoline, whereas ethanol, acetaldehyde, formaldehyde and methane emissions increase with the increasing ethanol content of gasoline (Yanowitz et al., 2013; Aakko and Nylund, 2003; Karlsson et al., 2008; Westerholm et al., 2008; Clairotte et al., 2013). In order to reduce the detrimental effects of pollution caused by vehicles, the emission standards for vehicle PM emissions are tightening globally. However, it must be noted that in the emission standard laboratory tests, the PM mass is measured directly after the tailpipe from a filter sample at an elevated temperature and thus represents mainly primary non-volatile PM emissions. As previous studies have demonstrated (e.g. Chirico et al., 2010; Nordin et al., 2013; Platt et al., 2013; Suarez-Bertoa et al., 2015), the secondary PM emissions formed from gaseous precursors can be significantly larger than primary PM emissions, meaning that the emission limits do not necessarily regulate secondary $\mathrm{PM}$ emissions.

In order to properly quantify vehicular engine emissions, the whole transformation chain, from freshly emitted primary PM and gaseous compounds to aged secondary PM measured in urban air quality stations, has to be better understood. The main objective of this study was to investigate primary particulate emissions and simulate the secondary aerosol formation potential of vehicular emissions with an oxidation flow chamber when the ethanol content in the fuel increases. The measurements were carried out with a modern FFV using fuels with three different ethanol contents $(10,85$ and $100 \%)$. A comprehensive set of instruments was used for measuring gaseous emissions together with the chemical composition and size distributions of the primary and secondary particles. All measurements were done with high time-resolution instruments and with the PAM flowthrough oxidation chamber. The measurement set-up enabled the characterization of the concentration and composition changes during different parts of the driving cycle.

\section{Experimental design}

\subsection{Measurement set-up and sampling}

The measurement set-up of this study is described in detail by Karjalainen et al. (2016). The article by Karjalainen et al. (2016) is focused on the primary and secondary emissions of a flex-fuel vehicle using E10 fuel, whereas this article is focused on the influences of the fuel alcohol content on particulate and gaseous emissions and their composition. In this study, the emissions from a flex-fuel passenger car (model year 2011; 1.4 L turbocharged direct-injection sparkignition (DISI) engine; Euro 5) were measured on a chassis dynamometer at $23^{\circ} \mathrm{C}$ using three different fuels (E10, E85 and E100; gasoline with 10, 85 and 100\% alcohol). A schematic figure of the measurement set-up is shown in Fig. S1 in the Supplement. The FFV vehicle was conditioned according to the manufacturer's instructions, and the adaptation of the car to the new fuel was monitored. Preparation needs and stability issues related to the FFV cars were based on an earlier project (Aakko-Saksa et al., 2014). The driving cycle was the New European Driving Cycle (NEDC; cycle profile shown in Fig. S2). NEDC totals $11.0 \mathrm{~km}$ divided into three test phases to study emissions at a cold start and with a warmed-up engine. The first part of the NEDC, the urban driving cycle (UDC), is repeated twice. The first phase, CSUDC, represents urban driving with a cold start (0-391 s; cold start UDC). The second phase, HUDC, represents typical urban driving (392-787 s; hot start UDC). The last phase, EUDC, represents highway driving (788-1180 s; extra-urban driving cycle). NEDCs were run on separate days in order to enable cold start conditions for each fuel. The test fuels were regular commercial E10 (max $10 \%$ ethanol), E85 ( $85 \%$ ethanol), and E100 (100\% ethanol). To avoid engine problems related to lean ethanol, deionized water was added to E100 to adjust the water content to $4.4 \%(\mathrm{~m} / \mathrm{m})$. A more detailed description of the car preparation and the driving cycle is given in the Supplement. Particle sampling was conducted with a partial exhaust sampling system (Ntziachristos et al., 2004) at the exhaust transfer line. The sampling system consisted of a porous tube diluter (a PTD with a dilution ratio, or DR, of 12$)$, a residence time chamber $(2.5 \mathrm{~s})$ and a secondary dilution conducted with a Dekati Diluter $(\mathrm{DR}=8$; Dekati Ltd., Kangasala, Finland). Regarding particle formation by nucleation, the sampling system mimics the exhaust dilution and nanoparticle formation processes in the atmosphere (Rönkkö et al., 2006; Keskinen and Rönkkkö, 2010). Two NEDC tests were conducted for each fuel. While some parameters were monitored similarly during both NEDC cycles (gaseous emissions, particle size distribution of primary exhaust particles; results shown in Table S1), the extensive study for the differences between primary and secondary particle emissions could only be conducted once per fuel.

The PAM chamber was used to evaluate the secondary aerosol formation potential during the NEDC. The PAM 
chamber is a small flow-through chamber that is irradiated with ultraviolet light (wavelengths of 185 and $254 \mathrm{~nm}$ ) to form high concentrations of oxidants $\left(\mathrm{O}_{3}, \mathrm{OH}\right.$ and $\left.\mathrm{HO}_{2}\right)$ that can initiate the production of secondary aerosol particles (Kang et al., 2007, 2011; Lambe et al., 2011). High oxidant concentrations (up to 1000-fold to atmosphere, with the same oxidant ratios as in the atmosphere) and high UV lights ensure the fast oxidation of compounds (Kang et al., 2007). The aging as the sample flows through the chamber is shown to represent up to several weeks of aging in the atmosphere (Kang et al., 2011; Ortega et al., 2013). The PAM chamber has been thoroughly characterized in previous studies. These studies include a loss characterization, a comparison to other chamber studies and a comparison on how the SOA formed in a chamber compares to the SOA observed in the ambient atmosphere and the SOA produced in large environmental chambers (e.g. Kang et al., 2007, 2011; Lambe et al., 2011, 2015; Tkacik et al., 2014; Peng et al., 2016). The PAM chamber used in this study is described in detail by Karjalainen et al. (2016). The PAM chamber was installed between the residence time chamber and the secondary dilution unit of the sampling system (Fig. S1). The particle instrumentation was located downstream of the secondary diluter. The sample flow through the PAM chamber was set to $9.75 \mathrm{~L} \mathrm{~min}^{-1}$, resulting in an average residence time of $84 \mathrm{~s}$. The voltage of the two UV lamps was at the maximum value of $190 \mathrm{~V}$. The sample conditions during the test were fairly stable; typically, the relative humidity was $60 \%$, the temperature was $22^{\circ} \mathrm{C}$ and the ozone concentration was $6 \mathrm{ppm}$. All cycles were first run without the PAM chamber to measure the primary emissions and then with the PAM chamber in order to study the formation of secondary particles. The secondary aerosol in the PAM chamber is formed when low volatility vapours condense on aerosols or form new particles. In the PAM chamber, these vapours may also condense onto walls, exit the chamber, or react with $\mathrm{OH}$, which leads to fragmentation and an increase in the saturation vapour pressure. Thus, the potential aerosol mass is underestimated if these chamber-related losses of low volatile vapours are not taken into account. We used the LVOC (low volatility organic compound) fate model presented by Palm et al. (2016) to estimate the losses of the condensing organic vapours in the PAM chamber (model available at https://sites.google.com/ site/pamwiki/hardware/estimation-equations). PM losses in the chamber were studied in the laboratory using a similar PAM chamber as in the measurements. The Supplement includes a detailed description of the loss calculations and the measured PM losses as a function of the particle size. Losses of primary PM in a PAM chamber (Fig. S3) are generally small, especially in the particle sizes that contain most of the aerosol mass: $25 \%$ at $50 \mathrm{~nm}, 15 \%$ at $100 \mathrm{~nm}$ and below $10 \%$ above $150 \mathrm{~nm}$. Also, because of the high condensational sink, over $95 \%$ of the LVOCs condensed on aerosol in all cases according to the LVOC fate model. Thus, the chamber-related losses of the LVOCs and the PM are small.
The PAM chamber was calibrated following the procedure described by Lambe et al. (2011). According to this offline calibration, the upper limit average of $\mathrm{OH}$ exposure during the experiments was $1.0 \times 10^{12}$ molec. $\mathrm{cm}^{-3} \mathrm{~s}$, corresponding to an atmospheric aging of 8 days (assuming an average $\mathrm{OH}$ concentration of $1.5 \times 10^{6}$ molec. $\mathrm{cm}^{-3}$ in the atmosphere; Mao et al., 2009), but the real $\mathrm{OH}$ exposure is lower due to high concentrations of $\mathrm{OH}$-reactive gases in the exhaust. This effect is significant, especially at the beginning of the cycle (CSUDC) when the concentrations are high. The average external $\mathrm{OH}$ reactivities (OHR) due to VOCs and $\mathrm{CO}$ in the CSUDC were 1246, 1141 and $3441 \mathrm{~s}^{-1}$ for E10, E85 and E100, respectively. The higher OHR of E100 is due to the high ethanol and aldehyde concentrations. After the CSUDC, the average OHR is below $90 \mathrm{~s}^{-1}$ for all fuels. More detailed OHR calculations are shown in Tables S2-S4.

We estimate the $\mathrm{OH}$ exposure in the PAM by using a simple photochemical box model made by William Brune, in which the differential equations describing the chemical reactions are solved using Euler's method. More details and the source code of the model are found in the PAM users manual (https://sites.google.com/site/pamusersmanual/ 7-pam-photochemistry-model). The free parameters in the model are photon fluxes at 254 and $185 \mathrm{~nm}$ of wavelength. Based on the offline calibration, the best-fit values for the photon fluxes are $7.3 \times 10^{14}$ and $1.3 \times 10^{13}$ photons $\mathrm{cm}^{-2} \mathrm{~s}^{-1}$ for the $254 \mathrm{~nm}$ wavelength and the $185 \mathrm{~nm}$ wavelength, respectively. The inputs for the model are OHR due to VOCs, $\mathrm{CO}$ concentration, $\mathrm{NO}$ concentration and $\mathrm{NO}_{2}$ concentration. In the model, $\mathrm{SO}_{2}$ is used as a proxy for VOCs; i.e. in the model, the OHR of $\mathrm{SO}_{2}$ equals the input OHR due to VOCs. This method is reasoned to be a realistic approximation by Peng et al. (2015) in terms of estimating the $\mathrm{OH}$ exposure.

The input values for the model are obtained from $1 \mathrm{~s}$ time resolution measurements of $\mathrm{CO}, \mathrm{NO}_{x}$ and total hydrocarbons (THC) corrected with the residence time distribution caused by the PAM chamber. The residence time distribution is obtained from the $\mathrm{CO}_{2}$ pulse experiment presented by Lambe et al. (2011). The concentrations of the individual VOCs are estimated using the high time-resolution THC concentration and the distribution of VOCs in different phases of the driving cycle (see Tables S2-S4). The OHR due to VOCs is obtained from these concentrations and the respective reaction constants. The $\mathrm{OH}$ exposure in the PAM was modelled at a 20 s time interval for each driving cycle, and the average $\mathrm{OH}$ exposures for the cycles are presented in Table 1.

\subsection{Particle measurements}

The Soot Particle Aerosol Mass Spectrometer (SP-AMS; Aerodyne Research Inc., Billerica, MA, USA) was used to measure the chemical composition of the emitted PM. The SP-AMS is a high-resolution time-of-flight aerosol mass spectrometer (HR-ToF-AMS) with an added laser (intracavity Nd:YAG, $1064 \mathrm{~nm}$ ) vaporizer. The dual vaporizer system 
Table 1. The average $\mathrm{OH}$ exposures during the driving cycles.

\begin{tabular}{lrrr}
\hline \multirow{2}{*}{ Fuel } & \multicolumn{3}{c}{ Average OH exposure $(\mathrm{h})$} \\
\cline { 2 - 4 } & CSUDC & HUDC & EUDC \\
\hline E10 & 6.2 & 35.3 & 33.3 \\
E85 & 5.0 & 13.0 & 14.1 \\
E100 & 3.9 & 16.2 & 22.5 \\
\hline
\end{tabular}

enables the real-time measurements of PM mass and the sizeresolved chemical composition of submicron non-refractory particulate matter, refractory black carbon and some metals and elements (e.g. $\mathrm{Na}, \mathrm{Al}, \mathrm{Ca}, \mathrm{V}, \mathrm{Cr}, \mathrm{Mn}, \mathrm{Fe}, \mathrm{Ni}, \mathrm{Cu}, \mathrm{Zn}$, $\mathrm{Rb}, \mathrm{Sr}$ and $\mathrm{Ba}$; Carbone et al., 2015). The HR-ToF-AMS is described in detail by Jayne et al. (2000) and DeCarlo et al. (2006), and the design of the SP-AMS is described by Onasch et al. (2012). In the SP-AMS, an aerodynamic lens is used to form a narrow beam of particles that is transmitted into the detection chamber. The particles are vaporized either by a tungsten vaporizer $\left(600^{\circ} \mathrm{C}\right)$ to analyze the non-refractory inorganic species and organics and/or with the laser in order to analyze the refractory black carbon (rBC) and the metals in addition to the inorganics and organics attached to these particles. The vaporized compounds are ionized using an electron impact ionization $(70 \mathrm{eV})$, and the formed ions are guided to the time-of-flight chamber and to the multi-channel plate (MCP) detector. A $5 \mathrm{~s}$ averaging time and a dual vaporization system, with both laser and tungsten oven operating, was used in the measurements. Only the V-mode data are used in this study. For the SP-AMS, the $1 \mathrm{~s}$ and $1 \mathrm{~min} 3 \sigma$ detection limits for submicrometer aerosol are $<0.31 \mu \mathrm{g} \mathrm{m}^{-3}$ and $<0.03 \mu \mathrm{g} \mathrm{m}^{-3}$, respectively, for all species in the V-mode (DeCarlo et al., 2006; Onasch et al., 2012). The $\mathrm{CO}_{2}$ concentrations during the measurements were significantly higher (up to $1450 \mathrm{ppm}$ ) than the atmospheric values, and thus the $\mathrm{CO}_{2}$ time series was used to correct the artefact caused by gaseous $\mathrm{CO}_{2}$.

The collection efficiency (CE) value, representing the fraction of the sampled particle mass that is detected by the MCP detector, is required for the calculation of the aerosol mass concentration measured by the AMS. Previous studies have shown that the collection efficiency of an aerosol mass spectrometer is affected by particle losses (i) during transit through the inlet and the lens, (ii) by particle beam divergence for both tungsten and laser vaporizers and by (iii) the bounce effects from the tungsten vaporizer (Matthew et al., 2008; Huffman et al., 2009; Onasch et al., 2012). Willis et al. (2014) demonstrated that particle morphology also affects the SP-AMS particle beam width, which in turn affects the collection efficiency through the overlap of the particle beam and the laser beam. Similar to Karjalainen et al. (2015), a CE of 1 was used in this study for all SP-AMS data. We acknowledge that it is likely that the collection efficiency might be underestimated for thinly coated primary emissions, whereas the used CE of 1 is likely closer to the correct value for heavily coated spherical secondary aerosol. Also, we note that gasoline soot, consisting of agglomerates with an average diameter below $90 \mathrm{~nm}$, will likely have a low transmission efficiency in the aerodynamic lens and thus might have a lower collection efficiency than regal black, which is typically used for calibration.

The particle number size distributions were measured using a time resolution of $1 \mathrm{~Hz}$ with a high-resolution lowpressure cascade impactor (HR-LPI, Dekati Ltd., Finland; Arffman et al., 2014) and an engine exhaust particle sizer (EEPS; TSI Inc., Shoreview, MN, USA; Mirme, 1994; Johnson et al., 2004). The particle number concentration was also measured with an ultrafine condensation particle counter (UCPC; TSI Inc.; model 3025). The UCPC was located downstream of an additional diluter (the operation principle based on the partial filtration of the sample; DR $=42$ ) to ensure that the concentrations to be measured were within its measurement range. All the data shown below have been corrected by a total dilution ratio for each instrument; thus, the presented values represent the tailpipe concentrations.

The particle number size distributions measured by the HR-LPI can be used to estimate how the particle losses in the PAM affect the measured total particle mass. If the measured HR-LPI number size distributions are corrected with the particle loss curve (Fig. S3 in the Supplement), the total mass calculated from the number size distribution increases by 9 $16 \%$ depending on the phase of the cycle and the fuel (see Table S5 for details). The masses measured by the SP-AMS cannot be corrected in a similar way, since the SP-AMS did not measure the particle size distributions; different chemical species might also be located in differently sized particles. Thus, the SP-AMS results presented in the following sections are not corrected for the particle losses in the PAM, but we expect that the loss of organic mass due to PAM wall losses to be of a similar order as the loss of total HR-LPI mass.

\subsection{Gaseous phase composition measurements}

The total hydrocarbon (THC) concentrations were measured with a flame ionization detector (FID) developed for the standardized exhaust emission test procedures of cars. The FID detects all carbon-containing compounds, for example carbonyl compounds, in addition to hydrocarbons (HC; Sandström-Dahl et al., 2010; Aakko-Saksa et al., 2014). In addition, samples were collected using Tedlar bags (Sigma-Aldrich, St. Louis, MO, USA) for subsequent analysis by a gas chromatograph (HP 5890 Series II, Al2O3 KCl PLOT column; Agilent Technologies, Santa Clara, CA, USA; an external standard method). The analyzed hydrocarbons (from $\mathrm{C}_{1}$ to $\mathrm{C}_{8}$ ) included methane, ethane, ethene, propane, propene, acetylene, isobutene, 1,3-butadiene, benzene, toluene, ethyl benzene and $\mathrm{m}-, \mathrm{p}$ - and o-xylenes. 
Table 2. A summary of the measured gaseous compounds, the instruments used and their detection limits.

\begin{tabular}{|c|c|c|c|}
\hline Instrument & Sampling & Measured compound & Detection limit \\
\hline $\begin{array}{l}\text { Flame ionization detector } \\
\text { (FID) }\end{array}$ & Online & $\begin{array}{l}\text { Total hydrocarbon concentra- } \\
\text { tion (THC) }\end{array}$ & $3 \mathrm{ppm}$ \\
\hline GC (HP 5890 Series II) & $\begin{array}{l}\text { Offline collection with Ted- } \\
\text { lar bag }\end{array}$ & $\begin{array}{l}\mathrm{C}_{1}-\mathrm{C}_{8} \text { hydrocarbons includ- } \\
\text { ing methane, ethane, ethene, } \\
\text { propane, propene, acetylene, } \\
\text { isobutene, 1,3-butadiene, ben- } \\
\text { zene, toluene, ethyl benzene } \\
\text { and } \mathrm{m} \text {-, p- and o-xylenes }\end{array}$ & $\begin{array}{l}0.02 \mathrm{~mol} \mathrm{~m}^{-3} \text {, corresponding } \\
\text { to approximately } 0.1 \mathrm{mg} \mathrm{km}^{-1} \text { for } \\
\text { methane, } 0.5 \mathrm{mg} \mathrm{km}^{-1} \text { for } 1,3- \\
\text { butadiene and } 0.7 \mathrm{mg} \mathrm{km}^{-1} \text { for } \\
\text { benzene }\end{array}$ \\
\hline $\begin{array}{l}\text { HPLC (Agilent } 1260 \mathrm{UV} \\
\text { detector; Nova-Pak C18 } \\
\text { column) }\end{array}$ & $\begin{array}{l}\text { Offline collection with } \\
\text { 2,4-dinitrophenylhydrazine } \\
\text { (DNPH) cartridges }\end{array}$ & $\begin{array}{l}\text { Aldehydes; formaldehyde, } \\
\text { acetaldehyde, acrolein, propi- } \\
\text { onaldehyde, crotonaldehyde, } \\
\text { methacrolein, butyraldehyde, } \\
\text { benzaldehyde, valeraldehyde, } \\
\text { m-tolualdehyde and hexanal }\end{array}$ & $0.01 \mathrm{mg} \mathrm{km}^{-1}$ \\
\hline $\begin{array}{l}\text { Fourier transformation } \\
\text { infrared (FTIR; Gasmet } \\
\text { CR2000) }\end{array}$ & Online & $\begin{array}{l}\mathrm{CO}, \mathrm{NO}, \mathrm{NO}_{2}, \mathrm{~N}_{2} \mathrm{O}, \text { am- } \\
\text { monia, methanol, ethanol, } \\
\text { isobutanol, n-butanol, ETBE, } \\
\text { formaldehyde and acetaldehyde }\end{array}$ & $\begin{array}{l}2-13 \mathrm{ppm} \text { at } 1 \mathrm{~s} \text { measurement in- } \\
\text { terval corresponding to mass con- } \\
\text { centration of } 1-15 \mathrm{mg} \mathrm{km}^{-1} \text { over } \\
\text { the European test cycle (Table S6) }\end{array}$ \\
\hline
\end{tabular}

Besides HCs, the selected aldehydes were analyzed by collecting diluted exhaust gas samples from a constant volume sampler (CVS) using 2,4-dinitrophenylhydrazine (DNPH) cartridges. The DNPH derivatives were extracted with an acetonitrile and water mixture and analyzed using HPLC (high performance liquid chromatography) technology (Agilent Technologies, 1260 UV detector; Nova-Pak C18 column, Waters Corporation, Milford, MA, USA). The aldehydes analyzed include formaldehyde, acetaldehyde, acrolein, propionaldehyde, crotonaldehyde, methacrolein, butyraldehyde, benzaldehyde, valeraldehyde, m-tolualdehyde and hexanal. Ethanol and a number of other compounds were measured online using a Fourier transformation infrared (FTIR) analyzer (Gasmet Technologies, Helsinki, Finland; CR2000). A summary of the measured gaseous compounds, the instruments used and their detection limits is shown in Table 2.

In these measurements, the sum of the hydrocarbons (HCs) analyzed by GC, FTIR and HPLC (the sum of HC from the $\mathrm{GC}+\mathrm{HC}$ portions of ethanol and acetaldehyde) resulted in an HC sum of $15 \mathrm{mg} \mathrm{km}^{-1}$ for E10, $30 \mathrm{mg} \mathrm{km}^{-1}$ for E85 and $216 \mathrm{mg} \mathrm{km}^{-1}$ for E100. The respective THC (FID) results were 22,30 and $193 \mathrm{mg} \mathrm{km}^{-1}$. This indicated that, on average, $73 \%$ of THCs (FID) were analyzed for E10, and $100 \%$ were analyzed for E85 and E100 by the GC, FTIR and HPLC.

\section{Results}

\subsection{Gas phase emissions}

The composition of the gas phase emissions was observed to change when the ethanol content of the fuel changed (Fig. 1). As the ethanol content increased, a clearly detectable decrease was observed in both the average $\mathrm{NO}_{x}$ and ammonia concentrations during the measurement cycle. A decrease in $\mathrm{NO}_{x}$ with increasing ethanol content is likely caused by decreased flame temperature (Turner et al., 2011). For instance, Turner et al. (2011) reported a a decrease of about 20 to $40^{\circ} \mathrm{C}$ in the exhaust temperature of a DISI engine when the ethanol content of the fuel changed from 0 to $100 \%$. Simultaneously, they reported that the $\mathrm{NO}_{x}$ emissions decreased from 8 to $0.5 \mathrm{~g} \mathrm{kWh}^{-1}$, with both values also slightly depending on the ignition timing and strategies. Decreasing trends in the $\mathrm{NO}_{x}$ emissions have also been observed by Maricq et al. (2012), who reported decreases of $20 \%$ in the $\mathrm{NO}_{x}$ emissions when the ethanol content increased to values of more than $17 \%$.

Ammonia is formed in the reactions of the three-way catalyst (TWC; Mejia-Centeno et al., 2007). In theory, ammonia formation is enhanced in slightly rich air-to-fuel ratios at high temperatures (aggressive accelerations) when sufficient $\mathrm{HC}$ and $\mathrm{NO}_{x}$ concentrations are present (Heeb et al., 2006; Mejia-Centeno et al., 2007; Li et al., 2010). Engine-out emissions were not measured here, but it is assumed that the $\mathrm{HC}$ and $\mathrm{NO}_{x}$ concentrations were not a limiting condition for ammonia formation. A decrease in the ammonia emissions for the E85 fuel indicates an enleanment of the conditions in the TWC catalyst when compared with those for the 


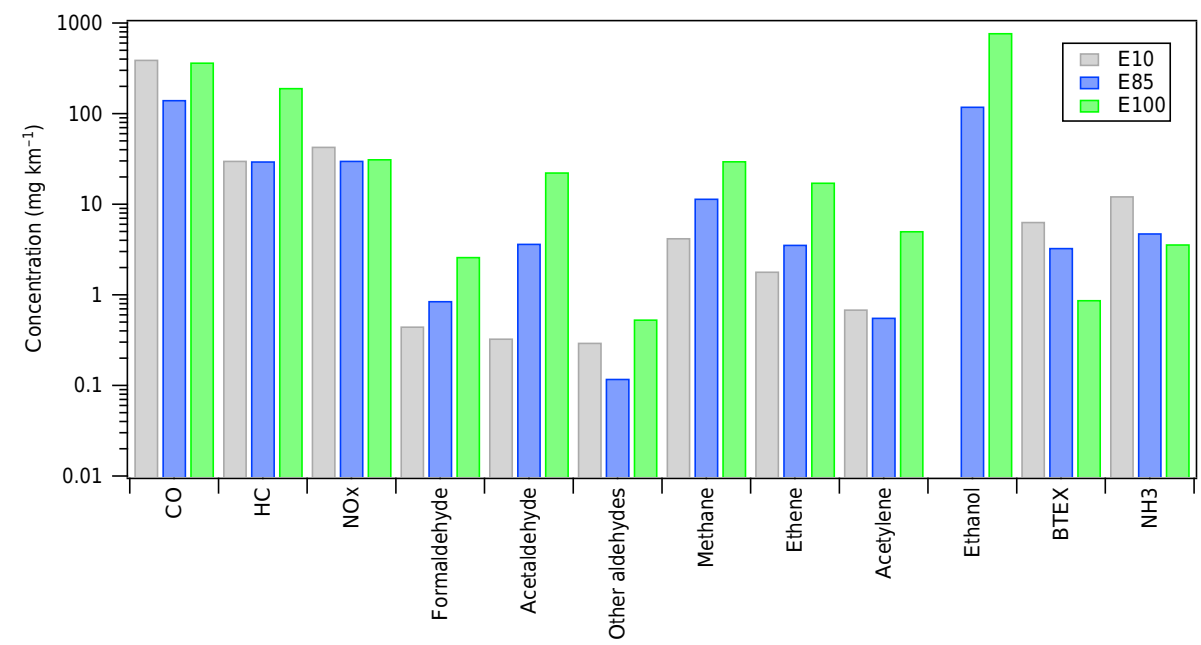

Figure 1. The mean concentrations of the gaseous compounds for different fuels measured during the NEDC.

E10 fuel. Clairotte et al. (2013) also reported lower ammonia emissions for the E85 fuel than for the E5 fuel. The decreases in both ammonia and $\mathrm{NO}_{x}$ lead to a decreased contribution to the secondary aerosol formation of ammonium nitrate in the atmosphere when the ethanol content is increased.

The amount of hydrocarbon emissions typically depends on the combustion conditions and exhaust after-treatment by catalytic devices. In this study, the test vehicle was equipped with a three-way catalytic converter with an effectivity which depends on the exhaust temperature and also on the hydrocarbon properties. In this study, the composition of the hydrocarbon emissions was observed to be strongly dependent on the ethanol content; as the ethanol content increased in the fuel, short-chain non-aromatic hydrocarbons and aldehydes increased in the exhaust, while a decreasing trend was observed for all measured aromatic hydrocarbon compounds. Also, as the ethanol content of the fuel increased, the exhaust concentrations of formaldehyde, acetaldehyde, ethanol, methanol, ethene and acetylene increased, whereas the exhaust concentrations of $\mathrm{NO}_{x}$, ammonia, PM and BTEX decreased (Fig. 1).

\subsection{Composition of primary particulate matter emissions}

The chemical composition of the primary particulate emissions was observed to vary for different fuels (Fig. 2). The concentration for each chemical component in units of $\mathrm{mg} \mathrm{km}{ }^{-1}$ for both the primary and secondary emissions is shown in the Supplement (Fig. S4). For E10, approximately half of the primary PM emissions was composed of $\mathrm{rBC}$, and the other half was composed of organics. The contribution of inorganic species (sulfate, nitrate, ammonium and chloride) to PM mass was small (1.2\%). From inorganic ions, sulfate had the highest contribution (47-67\% of the mass of the inorganic ions) for all fuels. A clear decrease in the rBC con-
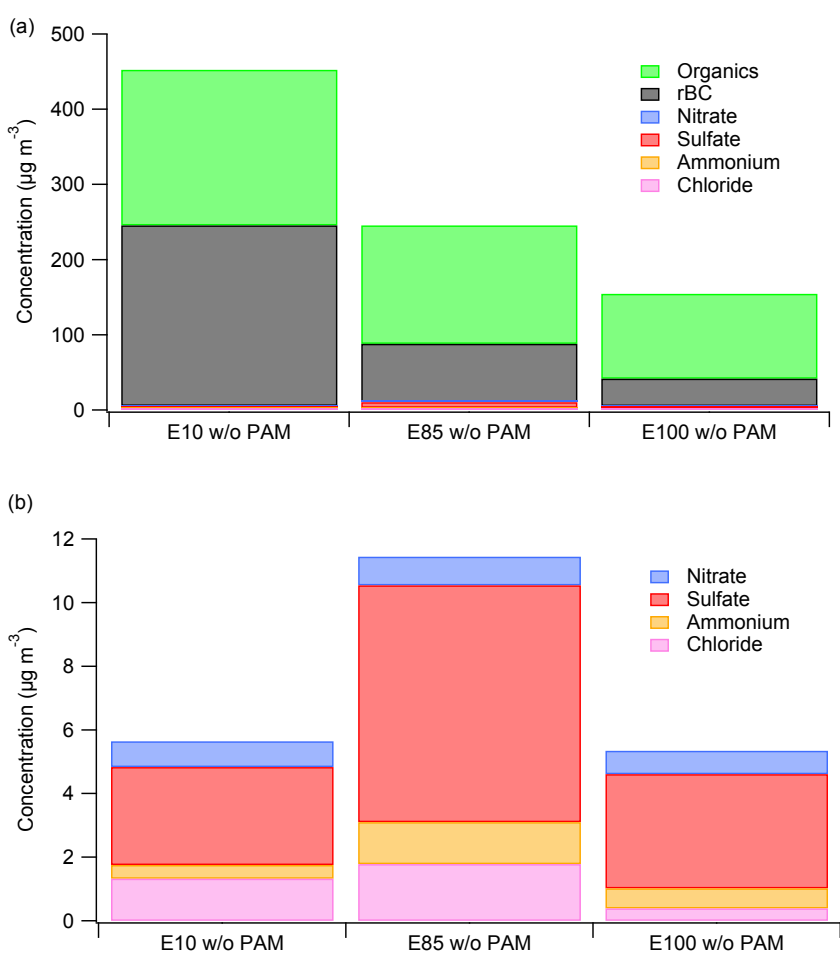

Figure 2. The chemical composition of the primary particulate emissions for E10, E85 and E100 (a). The concentrations of the inorganic ions (b).

centration and its contribution to the total emitted primary $\mathrm{PM}$ was observed as the ethanol content of the fuel increased (E10, rBC 53\%; E85, rBC 31\%; E100, rBC 25\%). The contribution of organic matter increased from $46 \%$ (E10) to $65 \%$ for E85 and $75 \%$ for E100. The organics-to-rBC ratios for the E10, E85 and E100 were 0.9, 2.1 and 3.1, respectively. 
Figure 3a shows the elemental ratios (oxygen-to-carbon ratio, $\mathrm{O}: \mathrm{C}$; hydrogen-to-carbon ratio, $\mathrm{H}: \mathrm{C}$ ) for the primary organic PM. All values are average values over the NEDC. The average elemental composition and elemental ratios $(\mathrm{O}: \mathrm{C}$ and $\mathrm{H}: \mathrm{C})$ are calculated using a method developed by Aiken et al. (2007) in which the elemental composition is calculated using all measured fragment ions observed in high-resolution mass spectra and $\mathrm{H}: \mathrm{C}$ and $\mathrm{O}: \mathrm{C}$ calibration factors derived from laboratory measurements of standard organic molecules. Canagaratna et al. (2015) further developed the elemental analysis to contain a wider range of organic species that are more representative of ambient organic aerosol (OA) species. The improved ambient ratios (IA) calculated according to the method published by Canagaratna et al. (2015) are also shown in Fig. 3. Rather similar O : C values $(0.35-0.4)$ were observed for the primary organic fraction for all fuels. The observed $\mathrm{H}: \mathrm{C}$ for the primary emissions of E10 and E85 $(\sim 1.5)$ was slightly lower than for E100 (1.7). The observed elemental ratios are comparable to the elemental ratios typically observed for hydrocarbonlike organic aerosol (HOA), representing traffic emissions in the ambient atmosphere and the elemental ratios observed in chamber studies (Tkacik et al., 2012; Timonen et al., 2013; Carbone et al., 2014; Canagaratna et al., 2015). We note that these $\mathrm{O}: \mathrm{C}$ ratios measured with an SP-AMS can be slightly higher than the ratios typically measured with an AMS for the primary emissions from gasoline vehicles due to the fact that the SP-AMS also detects the refractory organic species $\left(\mathrm{rCO}_{x}\right)$ incorporated on the structures of black carbon particles (Corbin et al., 2014).

\subsection{Composition of secondary aerosol simulated with a PAM chamber}

The secondary aerosol formation in the PAM chamber increased the contribution of both organic and inorganic compounds (Fig. 4). For all fuels, most of the particulate matter observed after the PAM chamber (E10, $89 \%$; E85, $79 \%$; E100, $61 \%$ ) consisted of organic compounds. The organicsto-rBC ratios for the secondary emissions of E10, E85 and E100 were 12, 8.3 and 3.1, respectively. The main inorganic ions observed after the PAM chamber were nitrate, sulfate and ammonium. When the ethanol content of the fuel increased, the relative contribution of the inorganic ions (E10, $4 \%$; E85, 12\%; E100, 19\%) in the exhaust PM increased after the PAM chamber.

\subsubsection{Organic aerosol}

Figure $3 \mathrm{~b}$ shows the average elemental ratios over the NEDC calculated for the organics from the SP-AMS data. For E10, an increase in $\mathrm{O}: \mathrm{C}$ (from 0.4 to 0.6 ) and a decrease in $\mathrm{H}: \mathrm{C}$ (from 1.55 to 1.45 ) was observed when the PAM chamber was used. In contrast, no change in $\mathrm{O}: \mathrm{C}$ or $\mathrm{H}: \mathrm{C}$ was observed for E85 when using the PAM chamber. For E100, a

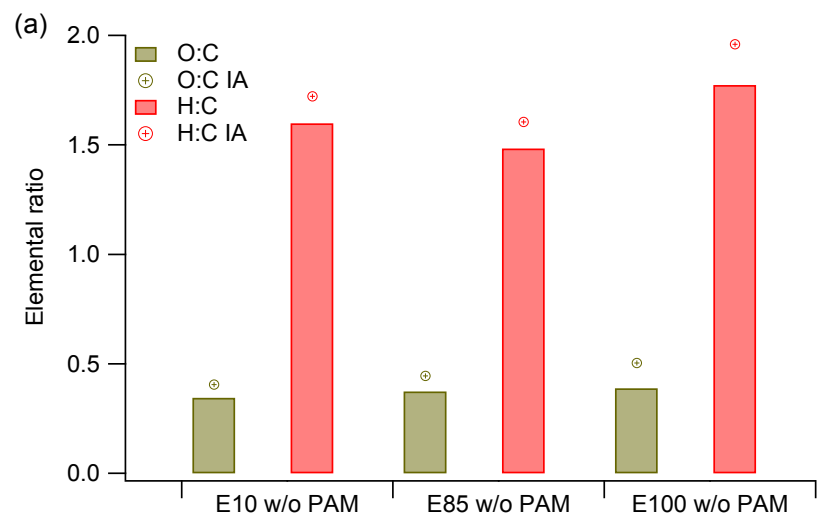

(b)

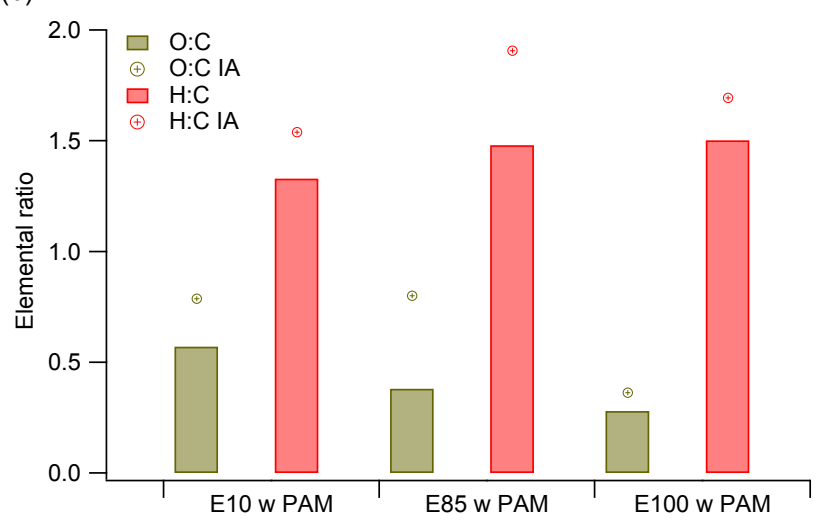

Figure 3. The average elemental composition $(\mathrm{O}: \mathrm{C}$ and $\mathrm{H}: \mathrm{C}$ ratios) of the emitted primary (a) and secondary (b) PM during the NEDC for E10, E85 and E100. The elemental composition is calculated using the original method developed by Aiken et al. (2007) and using a revised method (marked with IA to indicate improved ambient) containing the more atmospherically relevant organic compounds developed by Canagaratna et al. (2015).

slight decrease in $\mathrm{O}: \mathrm{C}$ and $\mathrm{H}: \mathrm{C}$ values was observed when using the PAM chamber. Similar elemental ratios (O : C 0.40.7) (Nordin et al., 2013; Suarez-Bertoa et al., 2015) have been observed for the secondary PM emissions in previous batch chamber studies. As shown for the gaseous exhaust compounds (Sect. 3.1), the composition and concentrations of the gaseous precursors change when the ethanol content of the fuel increases, also causing a clear change in the observed secondary aerosol composition and the oxidation state.

Figure 5 shows the contribution of the different organic fragments $\mathrm{C}_{x} \mathrm{H}_{y}$ (hydrocarbons with $\mathrm{C}_{x} \mathrm{H}_{y}^{+}$), $\mathrm{C}_{x} \mathrm{H}_{y} \mathrm{O}$ (fragments with one oxygen atom $\mathrm{C}_{x} \mathrm{H}_{y} \mathrm{O}^{+}$, e.g. $\mathrm{CO}^{+}$and $\mathrm{CHO}^{+}$) and $\mathrm{C}_{x} \mathrm{H}_{y} \mathrm{O}_{z}$ (hydrocarbon compounds containing several oxygen atoms $\mathrm{C}_{x} \mathrm{H}_{y} \mathrm{O}_{z, z>1}^{+}$, e.g. $\mathrm{CO}_{2}^{+}$) for all the fuels with and without the PAM. The contribution of $\mathrm{C}_{x} \mathrm{H}_{y} \mathrm{O}^{+}$ to organics increased after the oxidation of the exhaust sample in the PAM chamber for all the fuels, whereas the contributions of $\mathrm{C}_{x} \mathrm{H}_{y} \mathrm{O}_{z, z>1}^{+}$and $\mathrm{C}_{x} \mathrm{H}_{y}^{+}$decreased. For E10, the contribution of the sum of the oxidized compounds 

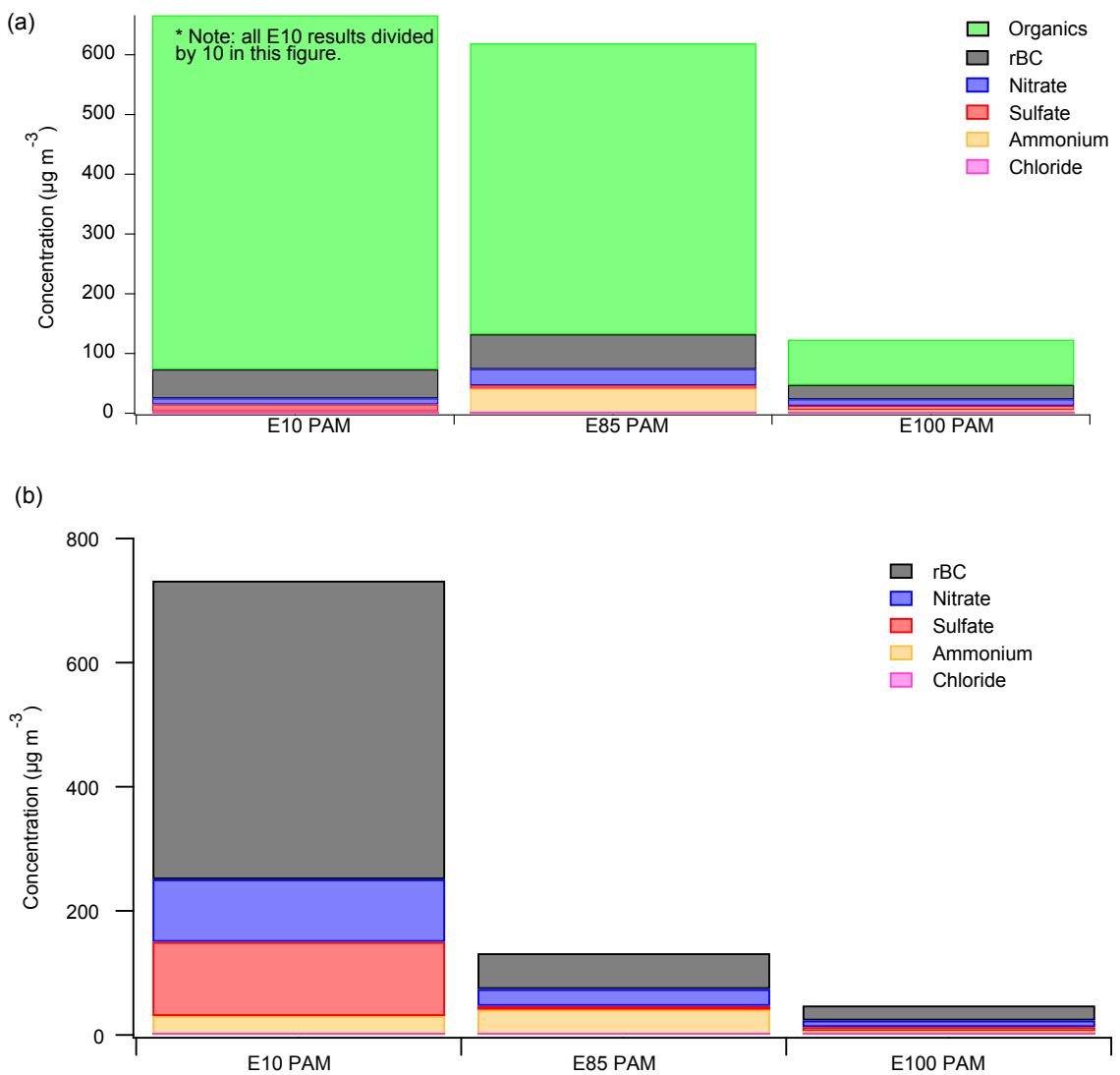

Figure 4. The composition of the particulate emissions after the PAM chamber for E10, E85 and E100 (a; in the left figure, all E10 results are divided by 10 in order to show all results in the same $y$ axis). The concentration of the inorganic ions and $\mathrm{rBC}$ after the PAM chamber for E10, E85 and E100 (b).

$\left(\mathrm{C}_{x} \mathrm{H}_{y} \mathrm{O}^{+}\right.$and $\left.\mathrm{C}_{x} \mathrm{H}_{y} \mathrm{O}_{z}\right)$ on exhaust $\mathrm{PM}$ increased from 35 to $62 \%$. For E85, the contribution of the oxidized organic compounds increased from 42 to $57 \%$, whereas for E100 the contribution of the oxidized organic compounds (approximately $62 \%$ ) remained the same with the PAM chamber when compared to the primary emissions. For all fuels, the total contribution of the oxidized compounds $\left(\mathrm{C}_{x} \mathrm{H}_{y} \mathrm{O}, \mathrm{C}_{x} \mathrm{H}_{y} \mathrm{O}_{z}\right)$ increased in the PAM chamber when compared to the contribution of hydrocarbons. For E10 and E85, the absolute concentration organic fraction and the total mass concentration of each organic hydrocarbon group increases in the PAM chamber, although the contribution of $\mathrm{CxHyO}$ slightly decreases, as shown in Fig. 5. Also, the mass spectra (Figs. S5-S16) show that in the hydrocarbon composition, clear differences can be observed. For E100, both the contributions and concentrations of the different organic families are similar with and without the PAM chamber; however, a change in the composition of these hydrocarbon groups is observed once again.

\subsubsection{Refractive black carbon}

Refractive black carbon (rBC) is formed during incomplete combustion and is always considered a primary emission; therefore, the $\mathrm{rBC}$ concentrations with and without the PAM chamber should be the same. Also, the measurements of the regulated emissions (Table S1) show that the cycles were repeatable and that the $\mathrm{rBC}$ concentrations for both cycles should be on the same level. However, some differences in the $\mathrm{rBC}$ concentrations were observed when the primary $\mathrm{rBC}$ concentrations were compared to the $\mathrm{rBC}$ results measured after the PAM chamber. For E85 and E100, a slight decrease in $\mathrm{rBC}$ after the PAM chamber was observed $(20-30 \%)$. This decrease is likely explained by losses of the primary PM in the chamber. Karjalainen et al. (2016) showed that the particle losses in the PAM chamber were on a similar level as the $\mathrm{rBC}$ losses seen here (approximately $8-30 \%$ for particle sizes of 50-400 nm). However, in contrast for E10, a clear increase in $\mathrm{rBC}$ (from 240 to $480 \mu \mathrm{g} \mathrm{m}^{-3}$ ) was observed when the emissions during the driving cycle were measured with the PAM chamber. In the SP-AMS, rBC is calculated as a sum of the carbon fragments $\mathrm{C}_{x}^{+}$. To explore the observed increase in $\mathrm{rBC}$ for $\mathrm{E} 10$ after the PAM chamber, the $\mathrm{C}_{x}$ frag- 
ments before and after the PAM chamber were studied. The increase after the PAM chamber for E10 was seen in all $\mathrm{C}_{x}$ fragments (Fig. S17; the ratios w PAM and w/o PAM from 1.6 to 2.8 for the $\mathrm{C}_{2}-\mathrm{C}_{5}$ fragments). The main fragments, $\mathrm{C}_{3}^{+}$and $\mathrm{C}_{2}^{+}$, of the $\mathrm{rBC}$ (contributions of 59 and $27 \%$, respectively) did not have any major interference from isobaric ions (ions observed in the same nominal mass). Larger fragments (e.g. $\mathrm{C}_{5}^{+}-\mathrm{C}_{9}^{+}$) had interfering isobaric organic compounds, but their contribution to the total mass was less than $10 \%$, and the influence of the interference was therefore considered to be insignificant.

There can be several reasons why the SP-AMS detected more $\mathrm{rBC}$ in the measurements conducted after the PAM chamber. Firstly, it must be noted that this increase in $\mathrm{rBC}$ was only observed for E10, which had the highest secondary aerosol formation potential and thus the largest increase in particle size in the PAM chamber. Previous studies have shown that the soot particles emitted by DISI vehicles are small, typically in the size range of 10-100 nm (Karjalainen et al., 2014). Due to restrictions from the aerodynamic lens, particles smaller than $50 \mathrm{~nm}$ are not effectively detected by the SP-AMS. The difference in the $\mathrm{rBC}$ results for $\mathrm{E} 10$ between the primary emissions and the emissions after the PAM is likely partly explained by the increased mean particle size due to the SOA formation increasing the efficiency through which the particles are detected by the SP-AMS (low volatility compounds formed in the PAM chamber condense on the surfaces of soot particles, increasing their aerodynamic size and thus the detection efficiency of soot and rBC). Also, Willis et al. (2014) demonstrated that the thick coating increases the collection efficiency by changing the particle morphology, thus decreasing the beam divergence and increasing the particle and laser beam overlap. Based on the increased mean particle size and the secondary-to-primary PM ratios, it can be assumed (see also Sect. 3.4 and the size distributions with and without the PAM chamber in Figs. S18 and S19) that for E10 the soot particles are heavily coated with SOA after the PAM chamber, and thus they are more effectively detected by the SP-AMS. In contrast, it has been shown that the dispersion of small and nonspherical particles in the aerodynamic lens inlet of the SP-AMS may cause particles to miss the laser vaporizer (Onasch et al., 2012). Also, based on previous studies, it is known that the black carbon particles emitted by engines are typically agglomerates with irregular shapes and diameters of 10-90 nm (Happonen et al., 2010; Lähde et al., 2010; Karjalainen et al., 2014; Liati et al., 2016), which also might have decreased the detection efficiency of the primary black carbon (soot) particles in this study. We also note that the losses for PM in the PAM chamber are dependent on particle size. Karjalainen et al. (2016) (Fig. S3 in the Supplement) found that the smallest particles incurred the largest losses in PM. However, based on this study, it is not possible to estimate which of the above-mentioned processes is the main reason for the observed $\mathrm{rBC}$ increase for E10.

\subsubsection{Inorganic ions}

In comparison to organics, the observed inorganic ion concentrations after the PAM chamber were moderate to low (ion contribution to PM mass for E10, 3.8\%; E85, $12 \%$; E100, 19\%). The main ions observed after the PAM chamber were sulfate, nitrate and ammonium for all fuels. In this study, the sulfur contents of the E10, E85 and E100 fuels were lower than $10 \mathrm{ppm}$ according to the specifications EN 228, EN 15293 and EN 15376, respectively. These facts strongly suggest that most of the observed sulfate emissions originate from lubricant oil, especially for E100.

\subsection{Primary-to-secondary particulate matter ratios}

Table 3 and Fig. 6 show the submicron PM concentrations for both the primary emissions and for the potential secondary aerosol emissions measured after the PAM chamber averaged over the driving cycle. PM was calculated as a sum of all SPAMS species in the size range of the SP-AMS $(30-800 \mathrm{~nm})$. The PM concentration measured after the PAM chamber is a sum of both the primary particulate emissions and the formed secondary aerosol. The secondary aerosol concentrations were calculated by subtracting the concentrations of the primary particles from the PM concentrations observed after the PAM chamber. It is likely that the wall losses in the chamber will somewhat decrease the primary aerosol concentrations and thus might increase the observed secondaryto-primary PM ratio when the particles go through the PAM chamber. However, based on laboratory PM loss measurements and modelled vapour losses, the influence of these on the results is estimated to be small. Also, one has to note that it is likely that in the PAM chamber new material originating from the gaseous phase will condense on the existing particles, which can change the particle morphology, increase the particle size and change their detection efficiency in the SP-AMS (Onasch et al., 2012; Willis et al., 2014). The observed secondary-to-primary PM ratios are thus also slightly affected.

Large differences in the concentrations between primary and secondary emissions were observed for the different ethanol content fuels. The largest primary and secondary PM concentrations were observed for E10 $\left(0.45 \mathrm{mg} \mathrm{m}^{-3}\right.$ for primary PM and $6.7 \mathrm{mg} \mathrm{m}^{-3}$ after the PAM chamber). A clear decrease in the primary $\mathrm{PM}$ emissions $\left(\mathrm{E} 85,0.24 \mathrm{mg} \mathrm{m}^{-3}\right.$; E100, $0.15 \mathrm{mg} \mathrm{m}^{-3}$ ) was seen as the ethanol content in the fuel increased. Similar to our results, Maricq et al. (2012) observed a decrease in the primary PM concentrations when the ethanol content of the fuel increased; however, they did not measure the secondary aerosol formation potential. The ethanol content of the fuel also had a large influence on the secondary aerosol formation potential. For E10, the PM measured after the PAM chamber was on average 14.7 times larger than the primary PM. For E85, the secondary PM emissions after the PAM chamber were on average approx- 


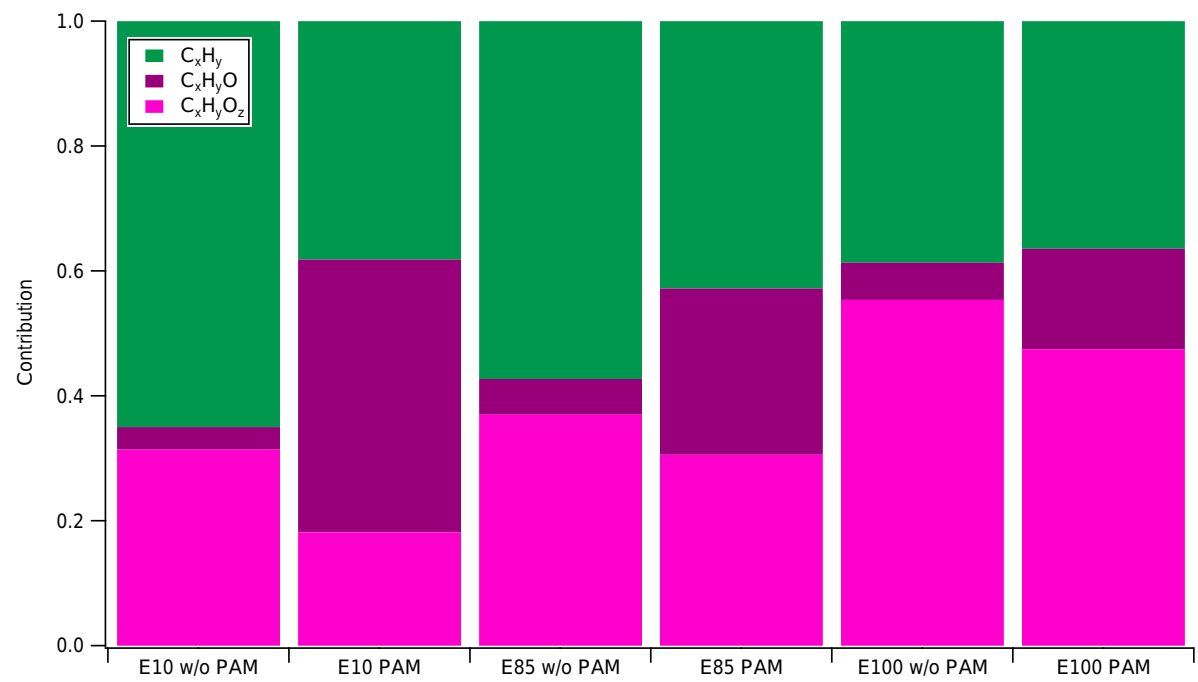

Figure 5. The contribution of the different organic fragments with and without the PAM chamber. $\mathrm{CH}$ refers to hydrocarbons $\left(\mathrm{C}_{x} \mathrm{H}_{y}\right), \mathrm{CHO}$ to fragments with one oxygen atom $\left(\mathrm{C}_{x} \mathrm{H}_{y} \mathrm{O}_{z}^{+}\right)$and $\mathrm{CHO}_{x}$ to compounds containing several oxygen atoms $\left(\mathrm{C}_{x} \mathrm{H}_{y} \mathrm{O}_{z}, z>1\right)$.

Table 3. The average concentrations of the main chemical compounds of PM (in $\mu \mathrm{g} \mathrm{m}^{-3}$ and $\mu \mathrm{km}^{-1}$ for individual species or mg km ${ }^{-1}$ for total mass) during the NEDC for the primary (w/o PAM) and secondary (PAM) emissions.

\begin{tabular}{|c|c|c|c|c|c|c|c|}
\hline Cycle & $\begin{array}{r}\text { Org } \\
\left(\mu \mathrm{g} \mathrm{m}^{-3} /\right. \\
\left.\mu \mathrm{g} \mathrm{km}^{-1}\right)\end{array}$ & $\begin{array}{r}\mathrm{NO}_{3} \\
\left(\mu \mathrm{g} \mathrm{m}^{-3} /\right. \\
\left.\mu \mathrm{g} \mathrm{km}^{-1}\right)\end{array}$ & $\begin{array}{r}\mathrm{SO}_{4} \\
\left(\mu \mathrm{g} \mathrm{m}^{-3} /\right. \\
\left.\mu \mathrm{g} \mathrm{km}^{-1}\right)\end{array}$ & $\begin{array}{r}\mathrm{NH}_{4} \\
\left(\mu \mathrm{g} \mathrm{m}^{-3} /\right. \\
\left.\mu \mathrm{g} \mathrm{km}^{-1}\right)\end{array}$ & $\begin{array}{r}\mathrm{CHL} \\
\left(\mu \mathrm{g} \mathrm{m}^{-3} /\right. \\
\left.\mu \mathrm{g} \mathrm{km}^{-1}\right)\end{array}$ & $\begin{array}{r}\mathrm{RBC} \\
\left(\mu \mathrm{g} \mathrm{m}^{-3} /\right. \\
\left.\mu \mathrm{g} \mathrm{km}^{-1}\right)\end{array}$ & $\begin{array}{r}\text { Total mass } \\
\left(\mu \mathrm{g} \mathrm{m}^{-3} /\right. \\
\left.\mathrm{mg} \mathrm{km}^{-1}\right)\end{array}$ \\
\hline E10 w/o PAM & 207.0/158.5 & $0.8 / 0.6$ & $3.1 / 2.4$ & $0.4 / 0.3$ & $1.3 / 1.0$ & $239.9 / 183.7$ & $452.6 / 0.346$ \\
\hline E10 PAM & $5928.3 / 4538.9$ & $101.1 / 77.4$ & $119.4 / 91.4$ & $30.6 / 23.4$ & $0.9 / 0.7$ & $481.3 / 368.5$ & $6661.7 / 5.10$ \\
\hline E85 w/o PAM & $157.3 / 122.1$ & $0.9 / 0.7$ & $7.4 / 5.8$ & 1.3/1.0 & $1.8 / 1.4$ & $76.7 / 59.5$ & $245.4 / 0.190$ \\
\hline E85 PAM & $487.1 / 378.0$ & $27.2 / 21.1$ & $5.9 / 4.6$ & $40.4 / 31.4$ & $0.6 / 0.5$ & $58.0 / 45.0$ & $619.3 / 0.48$ \\
\hline E100 w/o PAM & $112.7 / 89.7$ & $0.7 / 0.6$ & $3.6 / 2.9$ & $0.6 / 0.5$ & $0.4 / 0.3$ & $36.3 / 28.9$ & $154.4 / 0.123$ \\
\hline E100 w PAM & $75.8 / 60.3$ & $10.8 / 8.6$ & $7.2 / 5.7$ & $4.7 / 3.7$ & $0.9 / 0.7$ & $24.0 / 19.1$ & $123.5 / 0.10$ \\
\hline
\end{tabular}

imately 2 times larger $\left(0.62 \mathrm{mg} \mathrm{m}^{-3}\right)$ than the primary PM emissions. For E100, a slight decrease in PM mass (E100, $0.12 \mathrm{mg} \mathrm{m}^{-3}$ ) was seen after the PAM chamber, indicating that either the secondary aerosol formation was insignificant (Fig. 2; Table 3) or extensive fragmentation decreased the observed PM mass. Previous studies (e.g. Tkacik et al., 2014) have shown that high $\mathrm{OH}$ exposures cause a reduction in the observed mass because of fragmentation, which forms light organic compounds that are more volatile and will evaporate from the particulate phase. In the case of E100, the fragmentation probably did not occur at the beginning of the cycle because of the low $\mathrm{OH}$ exposure. The corresponding secondary-to-primary PM ratios were 13.4 and 1.5 for E10 and E85, respectively.

The influence of the fuel composition on secondary aerosol formation has been studied in only a few articles. Suarez-Bertoa et al. (2015) studied the secondary aerosol formation potential of exhaust for vehicles using high ethanol content fuels (E75 and E85). They used a batch chamber in their study and found that the secondary aerosol, mostly sec- ondary organic aerosol (SOA), was on average 3 times higher than the primary emissions for high ethanol content fuels; however, they did not measure the secondary aerosol for a standard low ethanol content fuel or for ethanol fuel (E100). This study shows that the SOA formation from high ethanol content is moderate to low when compared to low ethanol content fuel. Suarez-Bertoa et al. (2015) also concluded that short-chain hydrocarbons could have a role in SOA formation, but not only the aromatic BTEX compounds. We observed an increase in ethanol and total hydrocarbon emissions as the ethanol content of the fuel increased; however, the secondary aerosol formation was observed to be lower for these high ethanol content fuels when compared to low ethanol content fuel (E10). In this study, the concentrations of BTEX and the secondary aerosol formation potential both decreased as the ethanol content of the fuel increased, indicating that the BTEX compounds had a large influence on secondary aerosol formation. This conclusion is in line with the results of Nordin et al. (2013), who found that light aro- 

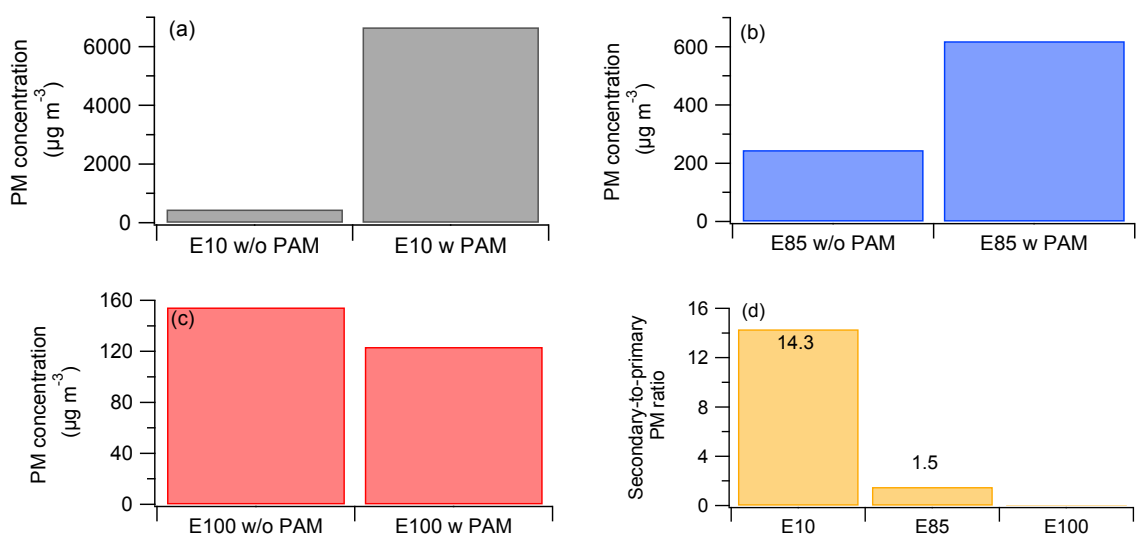

Figure 6. The primary submicron PM concentrations in the exhaust emissions measured without the PAM chamber and the submicron PM concentrations measured with the PAM chamber for E10 (a), E85 (b) and E100 (c). The secondary-to-primary PM ratio for the submicron PM mass in the exhaust calculated from the SP-AMS measurements (d). The concentration of the secondary particulate emissions was calculated by subtracting the concentration of the primary PM from the PM measured after the PAM chamber.

matic precursors (C6-C9) were responsible for $60 \%$ of the formed SOA in a batch-type smog chamber.

Tkacik et al. (2014) studied the secondary aerosol formation from in-use vehicle emissions using a PAM chamber in a highway tunnel in Pittsburgh. Similar to our study, they observed secondary-to-primary PM ratios of up to 10 inside the tunnel. They also found that the peak in the secondary aerosol production occurred under conditions equivalent to 2-3 days of atmospheric oxidation. With higher $\mathrm{OH}$ oxidation values, they saw a decrease in secondary aerosol formation due to continued oxidation fragmenting the carbon compounds. In our experiments, the equivalent atmospheric age was approximately 3.9-6.2 $\mathrm{h}$ during the CSUDC, when the most SOA formation took place. Thus, our results are likely on the lower end compared to the maximum secondary aerosol formation potential, but similar $\mathrm{OH}$ exposures are reached when compared to SOA formation studies conducted with batch chambers (e.g. Platt et al., 2013; Gordon et al., 2014a; Nordin et al., 2013).

\subsection{Predicted SOA formation}

The SOA yield is defined as (Odum et al., 1996)

$Y=\frac{\Delta M_{\mathrm{O}}}{\Delta \mathrm{HC}}$

where $\Delta M_{\mathrm{O}}$ is the formed secondary organic mass and $\Delta \mathrm{HC}$ is the reacted precursor mass. Using Eq. (1), the measured VOCs and the previously measured yields for these VOCs, we can analyze why the SOA formation potential decreases as the ethanol content in the fuel increases. We assumed that $\triangle \mathrm{HC}$ equals the measured VOC concentration before the PAM. Similarly to Platt et al. (2013), we use low $\mathrm{NO}_{x}$ yields to get an upper limit for SOA formation. The yields are listed in Table 4. For ethylbenzene, the SOA yield of $\mathrm{m}$ xylene (0.38) was used (Ng et al., 2007; Platt et al., 2013).
According to Volkamer et al., (2009), the acetylene $\left(\mathrm{C}_{2} \mathrm{H}_{2}\right)$ SOA yield strongly depends on the liquid water content of the aerosol. Here, a value of 0.1 was assumed. The yields are corrected with corresponding wall-loss correction factors (Table 4) presented by Zhang et al. (2014).

The contribution of each measured VOC to the predicted SOA is shown in the Supplement (Tables S2-S4; Figs. S20$\mathrm{S} 22$ ). According to the predictions, the decrease in the SOA formation is caused by the decrease in aromatic compounds in the exhaust when the ethanol content in the fuel is increased. The comparison between the predictions and the measurements is shown in Fig. S23. The trends in the predictions generally agree with the measurements except for E100, where the predicted SOA is higher than for E85. The predicted SOA for E100 mostly comes from acetylene (Fig. S22). Thus, the measured SOA formation potential seems to depend rather on the aromatic concentrations than on the acetylene.

\subsection{Temporal variation in chemical composition during the driving cycle for primary and secondary emissions}

Figure 7 and Figs. S5-S16 in the Supplement show the time series of the organic, inorganic ion and refractory black carbon (rBC) compounds for the primary emissions (panel a) and the emissions after the PAM chamber (panel b). The measurement set-up used and the primary and secondary particulate emissions for E10 have been published previously by Karjalainen et al. (2016). For E10, the largest PM, organic, $\mathrm{rBC}$ and nitrate emissions were observed at the beginning of the cycle during the first acceleration (Karjalainen et al., 2015). Occasional increases were also observed during deceleration and engine braking conditions (Rönkkö et al., 2014; Karjalainen et al., 2014). At the end of the cycle, when the speed was above $70 \mathrm{~km} \mathrm{~h}^{-1}$, the largest inorganic 
Table 4. The SOA yields for the different VOCs. The vapour wall-loss correction factors are obtained from Zhang et al. (2014).

\begin{tabular}{lrrrrl}
\hline Compound & Yield $\left(\right.$ low $\left.\mathrm{NO}_{x}\right)$ & Yield $\left(\right.$ high NO$\left._{x}\right)$ & Correction $\left(\right.$ low $\mathrm{NO}_{x}$ ) & Correction (high $\mathrm{NO}_{x}$ ) & Reference \\
\hline Toluene & 0.3 & 0.13 & 1.9 & 1.13 & Ng et al. (2007) \\
Benzene & 0.37 & 0.28 & 1.8 & 1.25 & Ng et al. (2007) \\
m- and p-Xylene & 0.38 & 0.08 & 1.8 & 1.2 & Ng et al. (2007) \\
1,3-Butadiene & - & 0.18 & - & - & Sato et al. (2011) \\
o-Xylene & 0.1 & 0.05 & - & - & Song et al. (2007) \\
Acetylene & 0.1 & - & - & - & Volkamer et al. (2009) \\
\hline
\end{tabular}
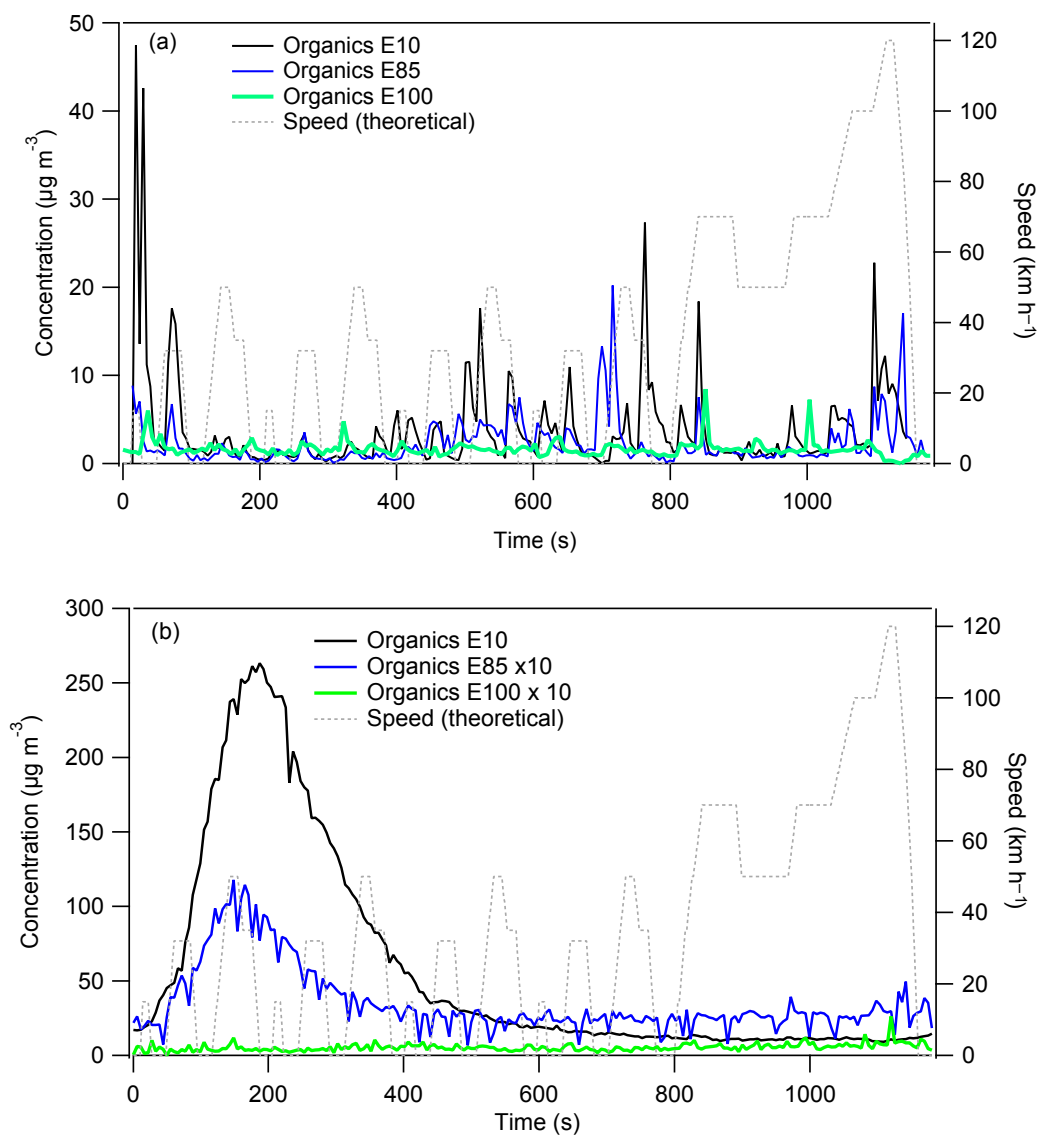

Figure 7. The time series of the organic compounds for the primary emissions (a) and for the emissions measured after the PAM chamber (b). The speed profile of the NEDC is also shown. The speed profile and the mass concentration in (b) do not correspond to each other directly due to the broad residence time distribution of the PAM chamber.

ion (sulfate, chloride and ammonium) emissions were observed. A moderate increase in organics and $\mathrm{rBC}$ was also observed at the end of the cycle.

Compared to E10, for which the highest primary organic emissions (peak concentration up to $25 \mathrm{mg} \mathrm{m}^{-3}$ ) were observed right after a cold start, for E85 and E100 the largest primary organics (peak concentration up to $\mathrm{E} 85,1.5 \mathrm{mg} \mathrm{m}^{-3}$; E100, $0.8 \mathrm{mg} \mathrm{m}^{-3}$ ) were measured either in the middle of the cycle or during the highway driving part at the end of the cycle. The time trend of the $\mathrm{rBC}$ emissions was similar for all fuels. Elevated rBC emissions were only seen at the begin- ning of the cycle and during the highway driving part of the cycle (Figs. S6, S10 and S16). The primary inorganic ion concentrations were the highest during the highway driving part of the cycle for E10 and E85. For E100, the primary inorganic ion levels were typically low, except for some elevated spikes that were observed for sulfate.

The time series observed for the secondary emissions was completely different when compared to the primary emissions. For E10 and E85, the cold start had a dominating role in secondary aerosol formation, with a clear increase after a cold start in the first part of the cycle (0-390 s). A simi- 


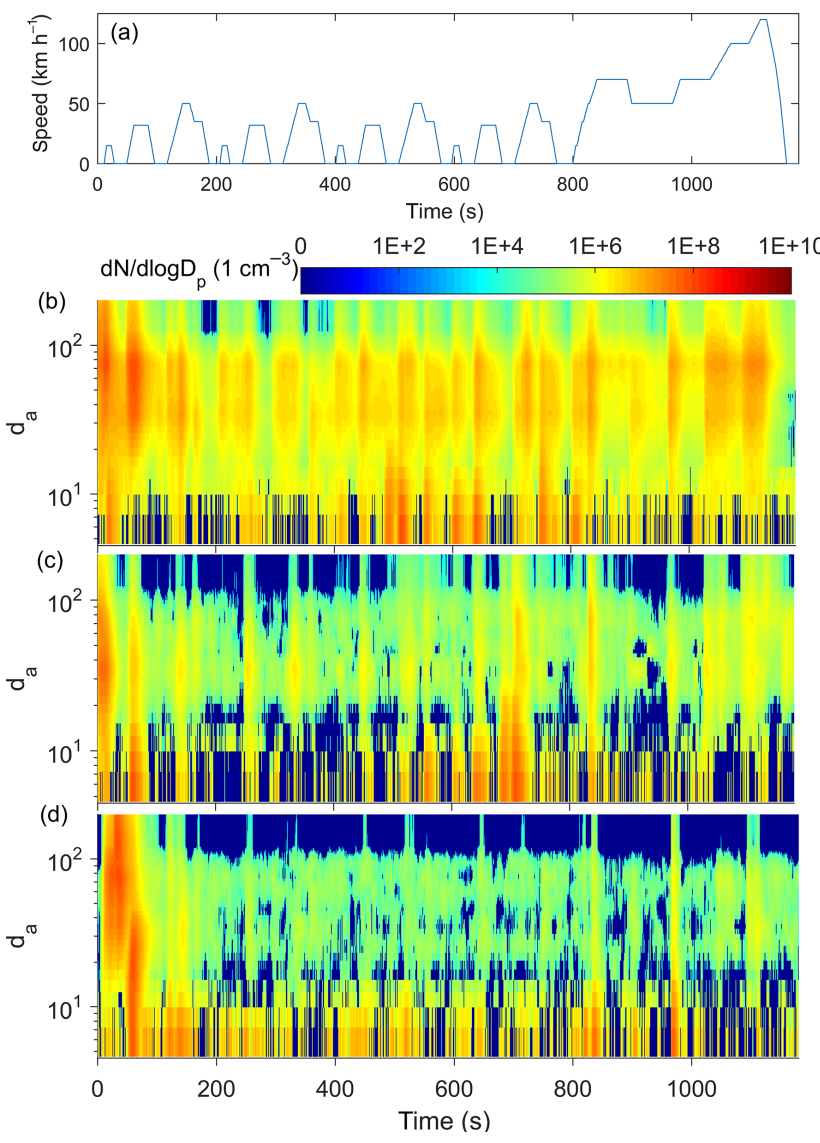

Figure 8. The number size distributions for the primary particle emissions. The measurements were made during the driving cycle for all tested fuels, E10 (b), E85 (c) and E100 (d). The driving cycle (NEDC) is shown in (a).

lar increase at the beginning of the cycle was not observed for E100. During the second part of the driving cycle (390$780 \mathrm{~s}$ ), the secondary organic concentrations stayed at a constant level until the end of the cycle for all fuels. In contrast for E100, the organic PM concentrations measured after the PAM chamber were stable through the cycle with no clear maxima. We note that the speed profile and the mass concentration in Fig. 7b do not correspond to each other directly due to the broad residence time distribution of the PAM chamber (Lambe et al., 2011). Still, the figure shows that the most SOA formation is caused by the cold engine and a cold aftertreatment at the beginning of the cycle for both E10 and E85.

The temporal behaviour of the ions during the driving cycle was very different when compared to the organics. After the PAM chamber, elevated nitrate concentrations were observed at the beginning of the cycle after the cold start and at the end of the cycle during the highway driving part. For E85 and E100, the nitrate concentrations measured after the PAM chamber were very low (Figs. S5-S16). Elevated sulfate concentrations for all fuels were measured after the PAM chamber in the middle part of the cycle and at the end during
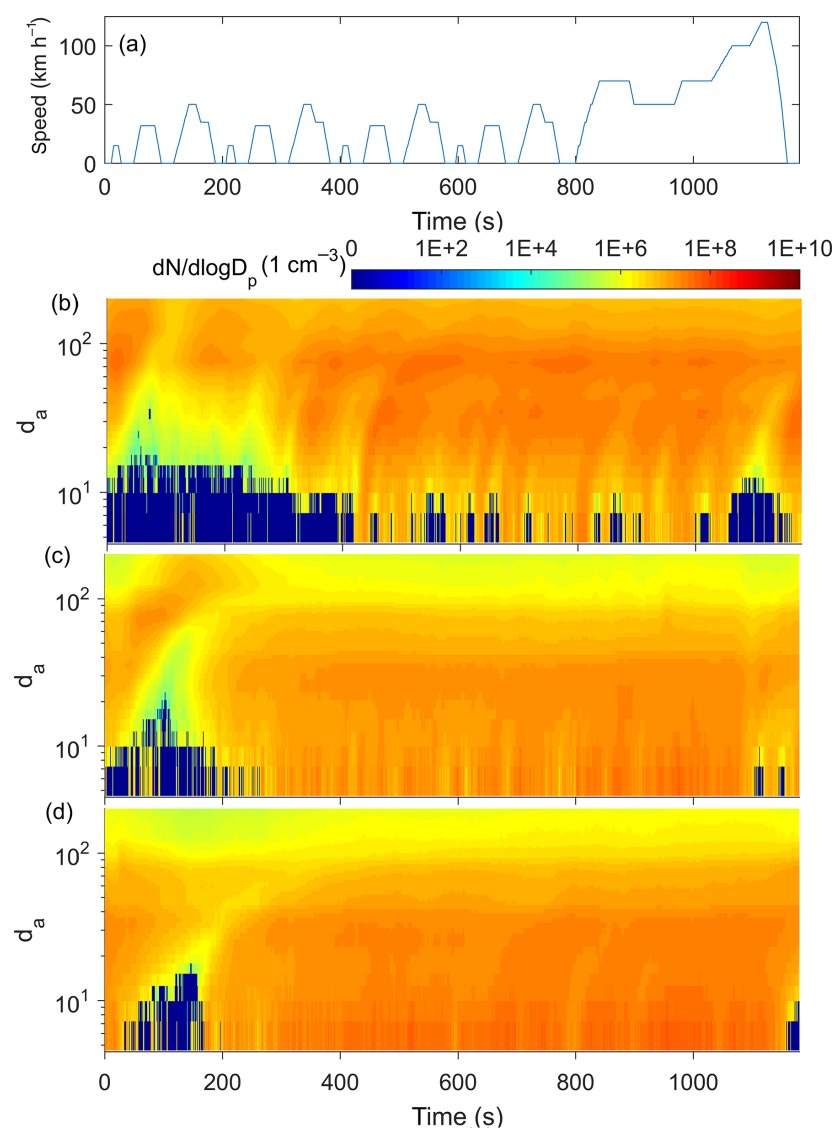

Figure 9. The number size distributions for the secondary particle emissions measured after the exhaust treatment by the PAM. The measurements were made during the driving cycle for all tested fuels, E10 (b), E85 (c) and E100 (d). The driving cycle (NEDC) is shown in (a).

the highway driving part of the cycle (Figs. S5-S16). Elevated ammonium concentrations were observed at the end of the cycle during the highway driving part for all fuels. The temporal behaviour of the ammonium concentration was observed to be correlated with nitrate, suggesting ammonium nitrate formation. Tkacik et al. (2014) measured high ammonium nitrate concentrations (forming from $\mathrm{NO}$ oxidation to $\mathrm{HNO}_{3}$ with subsequent neutralization with $\mathrm{NH}_{3}$ ) that exceeded the SOA concentrations by a factor of 2 in measurements conducted in a highway tunnel. In this study, the average contribution of inorganic ions to the submicron PM mass was always below $20 \%$ and the contribution of ammonium nitrate was always significantly lower when compared to SOA.

\subsection{Temporal variation in size distributions of primary and secondary PM}

The number size distributions of the emitted particles were measured in order to understand the changes in the particulate phase when the driving conditions, such as speed and 
engine load, rapidly change. Figure 8 shows the number size distributions of the primary particles for each fuel as a function of time during the driving cycle. It can be seen that for the E10 fuel, the emissions of particles in the size range of $25-100 \mathrm{~nm}\left(D_{p}\right)$ were far higher than for E85 and E100. The emissions of the particles in the size range of $25-100 \mathrm{~nm}$ depended on the driving condition, so they existed mostly during the acceleration parts of the NEDC. These particles were most likely soot-mode particles consisting of black carbon. This is in line with the chemical composition results, which show that as the ethanol content of the fuel increased, the rBC emissions decreased.

Figure 8 also shows that from the viewpoint of particle number, the role of a cold start remained important with the fuels of high ethanol content. In fact, most of the particulate emissions for E100 are related to the cold start situation. For E10, $37 \%$ of the particle number was emitted during the first part of the cycle (CSUDC; 0-391 s; see Karjalainen et al., 2016). For $\mathrm{E} 85$ and $\mathrm{E} 100,43$ and $77 \%$ of the particle number was emitted during the CSUDC. Although it seems that the mean particle diameter slightly decreased when the ethanol content of the fuel increased, the larger soot-mode particles existed in the exhaust with all fuels. However, the concentration of the soot-mode particles over the NEDC decreased significantly when the amount of ethanol in the fuel was increased. Fuel changes also clearly affected the nanoparticle emissions; the emissions of nanoparticles decreased as the ethanol content of the fuel increased. Still, there were systematic and identifiable sub- $10 \mathrm{~nm}$ particle emission bursts with all the fuels tested, possibly linking the emissions of the smallest particles to lubricant oil consumption. Overall, we note that the effect of the fuel was larger for soot-mode particles than for nanoparticles. At the end of the cycle (800$1000 \mathrm{~s}$ ), two distinct peaks were seen for E100. The same peaks were identified in the rBC time series (see Fig. S16 in the Supplement).

The aerosol formation after the engine cold start was also clearly seen in the secondary aerosol concentrations (Fig. 9). The largest particles downstream of the PAM chamber were measured about $100 \mathrm{~s}$ after the cycle start when enough diluted exhaust gas was accumulated in the PAM chamber. Under high pollutant concentrations, practically no sub- $20 \mathrm{~nm}$ particles were measured downstream of the PAM chamber. After around $200 \mathrm{~s}$ of the cycle, the vehicle engine and the exhaust system had seemingly warmed up, and the particle size distributions for the rest of the cycle had similar patterns. As the fuel ethanol content increases, the size of the particles during the cold start as well as during the whole cycle decreases. As the ethanol content of the fuel increased, a clear increase in the smallest nanoparticles after the PAM chamber was observed, indicating smaller amounts of condensable vapours to grow particles inside the PAM chamber. Because the nanoparticle emissions were observed to decrease as the ethanol content of the fuel in primary emissions increased, this observation indicates that small particles can also form in the PAM chamber via condensation on particles smaller than the lower size limit of the instruments used or via nucleation. Figure 9 indicates that the average particle size in the exhaust emissions decreased as the ethanol content increased (also shown for the average values in Fig. S18). This will likely affect the efficiency of how these particles are detected with the SP-AMS since the collection efficiency of the aerodynamic lens used in the SP-AMS sharply decreases in particle sizes below $30 \mathrm{~nm}$. It should be taken into account that the size distributions shown here are number size distributions, not mass size distributions.

\section{Conclusions}

Ethanol is used in fuels to decrease the $\mathrm{CO}_{2}$ emissions of transportation and thus to reduce the adverse climate effects of traffic. This study shows that the use of these fuels produces benefits by decreasing exhaust PM concentrations, thus having a positive influence on air quality. A decrease in PM was seen in both primary emissions and the secondary aerosol formation potential of the exhaust emitted by a modern flex-fuel DISI vehicle.

The composition of the primary emissions was observed to change as the ethanol content of the fuel increased. The relative contribution of $\mathrm{rBC}$ to the particulate matter decreased, whereas the contribution of organic particulate matter and inorganic ions increased. The organics-to-rBC ratios for the primary emissions of E10, E85 and E100 were 0.9, 2.1 and 3.1, respectively. For all fuels, most of the particulate matter observed after the PAM chamber consisted of organic compounds (E10, 89\%; E85, $79 \%$; E100, $61 \%)$. The organicsto-rBC ratios measured after the PAM chamber for E10, E85 and E100 were 12, 8.3 and 3.1, respectively. The role of the cold start was observed to dominate in the secondary aerosol formation for E10 and E85. For E100, no significant increase in the secondary aerosol concentrations due to the cold start was observed. As the ethanol content of the fuel increased, secondary aerosol formation was observed to decrease significantly. For E10, the secondary aerosol formation was significantly larger than the primary PM emissions, with a secondary-to-primary PM ratio of 13.4, whereas for E100 a similar increase in the PM mass after the PAM chamber was not observed.

The large difference in the exhaust secondary aerosol formation between E10 and fuels with a higher ethanol content can be explained by considering the emissions of potential aerosol precursors. The exhaust emissions for low-ethanol fuels contained fewer short-chained organic species (ethanol, formaldehyde, acetaldehyde, methane and ethene) than the exhaust for E85 and E100, but significantly more aromatic compounds (benzene, toluene, ethyl benzene and xylenes). The compounds with a low number of carbon atoms are unlikely to form secondary aerosol due to their high vapour pressure; conversely, aromatic compounds are considered the 
most important SOA precursors among the anthropogenic hydrocarbons. Their major atmospheric sink is the reaction with the hydroxyl radical (Andino et al., 1996). It is also known that the SOA yields tend to decrease at high $\mathrm{NO}_{x}$ concentrations (Henze et al., 2008). In our case, both the $\mathrm{NO}_{x}$ concentration and the aromatics concentration decreased when the fuel was changed from E10 to high-ethanol fuels, but the $\mathrm{NO}_{x}$ decrease was comparatively minor. At the same time, the concentration of OH-reactive, short-chained organic species increased. These factors together cause a strong decrease in the production of aromatic hydrocarbon oxidation products, which in turn decreases the production of secondary organic aerosol. The decrease in aromatic emissions may by itself be enough to explain the SOA reduction, but one should not omit the effect of the added reactivity presented by increased ethanol emissions, for example, which may have an inhibiting effect by taking up a larger fraction of $\mathrm{OH}$ (similar to the inhibition caused by isoprene in the case of biogenic SOA formation; see Kiendler-Scharr et al., 2009). The reduction in $\mathrm{NO}_{x}$ should in principle increase the SOA formation, but the effect is minor compared to the inhibiting causes.

This study shows that the SP-AMS combined with the PAM chamber is an efficient tool to investigate the differences in the secondary aerosol formation potential between vehicle technologies (fuels) with a high time resolution taking the driving conditions into account. However, the study strongly recommends including a high time-resolution particle size distribution measurement parallel with the SP-AMS. In general, the information gathered in this study is important for legislative purposes as well as for modellers and city authorities establishing emission estimates.

Data availability. The data used in this publication are available to the community and can be accessed by request to the corresponding author.

\section{The Supplement related to this article is available online at doi:10.5194/acp-17-5311-2017-supplement.}

Competing interests. The authors declare that they have no conflict of interest.

Acknowledgements. The authors gratefully acknowledge support from the following: the Cluster for Energy and Environment (CLEEN Ltd); Measurement, Monitoring and Environmental Assessment (MMEA), work package 4.5.2.; the Swedish Research Council FORMAS; and Annex 44 within the Advanced Motor Fuels (AMF) Agreement of the International Energy Agency (IEA). Sanna Saarikoski thanks the Academy of Finland for funding her work (grant no. 259016).
Edited by: D. Farmer

Reviewed by: three anonymous referees

\section{References}

Aakko, P. and Nylund, N.: Particle Emissions at Moderate and Cold Temperatures Using Different Fuels, SAE Technical Paper 200301-3285, doi:10.4271/2003-01-3285, 2003.

Aakko-Saksa, P., Rantanen-Kolehmainen, L., and Skyttä, E.: Ethanol, Isobutanol, and Biohydrocarbons as Gasoline Components in Relation to Gaseous Emissions and Particulate Matter, Environ. Sci. Technol., 48, 10489-10496, doi:10.1021/es501381h, 2014.

Aiken, A. C., DeCarlo, P. F., and Jimenez, J. L.: Elemental analysis of organic species with electron ionization highresolution mass spectrometry, Anal. Chem., 79, 8350-8358, doi:10.1021/ac071150w, 2007.

Andino, J. M., Smith, J. N., Flagan, R. C., Goddard, W. A., and Seinfeld, J. H.: Mechanism of atmospheric photooxidation of aromatics: A theoretical study, J. Phys. Chem.-Us, 100, 1096710980, doi:10.1021/Jp9529351, 1996.

Arffman, A., Yli-Ojanperä, J., Kalliokoski, J., Harra, J., Pirjola, L., Karjalainen, P., Rönkkö, T., and Keskinen, J.: A High-Resolution Low-Pressure Cascade Impactor, J. Aerosol Sci., 78, 97-109, 2014.

Arnold, F., Pirjola, L., Ronkko, T., Reichl, U., Schlager, H., Lahde, T., Heikkila, J., and Keskinen, J.: First online measurements of sulfuric acid gas in modern heavy-duty diesel engine exhaust: implications for nanoparticle formation, Environ. Sci. Technol., 46, 11227-11234, 10.1021/es302432s, 2012.

Canagaratna, M. R., Onasch, T. B., Wood, E. C., Herndon, S. C., Jayne, J. T., Cross, E. S., Miake-Lye, R. C., Kolb, C. E., and Worsnop, D. R.: Evolution of Vehicle Exhaust Particles in the Atmosphere, J. Air Waste Manage., 60, 1192-1203, doi:10.3155/1047-3289.60.10.1192, 2010.

Canagaratna, M. R., Jimenez, J. L., Kroll, J. H., Chen, Q., Kessler, S. H., Massoli, P., Hildebrandt Ruiz, L., Fortner, E., Williams, L. R., Wilson, K. R., Surratt, J. D., Donahue, N. M., Jayne, J. T., and Worsnop, D. R.: Elemental ratio measurements of organic compounds using aerosol mass spectrometry: characterization, improved calibration, and implications, Atmos. Chem. Phys., 15, 253-272, doi:10.5194/acp-15-253-2015, 2015.

Carbone, S., Aurela, M., Saarnio, K., Saarikoski, S., Timonen, H., Frey, A., Sueper, D., Ulbrich, I. M., Jimenez, J. L., Kulmala, M., Worsnop, D. R., and Hillamo, R. E.: Wintertime Aerosol Chemistry in Sub-Arctic Urban Air, Aerosol Sci. Tech., 48, 313-323, doi:10.1080/02786826.2013.875115, 2014.

Carbone, S., Onasch, T., Saarikoski, S., Timonen, H., Saarnio, K., Sueper, D., Rönkkö, T., Pirjola, L., Häyrinen, A., Worsnop, D., and Hillamo, R.: Characterization of trace metals on soot aerosol particles with the SP-AMS: detection and quantification, Atmos. Meas. Tech., 8, 4803-4815, doi:10.5194/amt-8-4803-2015, 2015.

Chirico, R., DeCarlo, P. F., Heringa, M. F., Tritscher, T., Richter, R., Prévôt, A. S. H., Dommen, J., Weingartner, E., Wehrle, G., Gysel, M., Laborde, M., and Baltensperger, U.: Impact of aftertreatment devices on primary emissions and secondary organic aerosol formation potential from in-use diesel vehicles: re- 
sults from smog chamber experiments, Atmos. Chem. Phys., 10, 11545-11563, doi:10.5194/acp-10-11545-2010, 2010.

Chirico, R., Clairotte, M., Adam, T. W., Giechaskiel, B., Heringa, M. F., Elsasser, M., Martini, G., Manfredi, U., Streibel, T., Sklorz, M., Zimmermann, R., DeCarlo, P. F., Astorga, C., Baltensperger, U., and Prevot, A. S. H.: Emissions of organic aerosol mass, black carbon, particle number, and regulated and unregulated gases from scooters and light and heavy duty vehicles with different fuels, Atmos. Chem. Phys. Discuss., 14, 16591-16639, doi:10.5194/acpd-14-16591-2014, 2014.

Clairotte, M., Adam, T. W., Zardini, A. A., Manfredi, U., Martini, G., Krasenbrink, A., Vicet, A., Tournie, E., and Astorga, C.: Effects of low temperature on the cold start gaseous emissions from light duty vehicles fuelled by ethanol-blended gasoline, Appl. Energ., 102, 44-54, doi:10.1016/j.apenergy.2012.08.010, 2013.

Corbin, J. C., Sierau, B., Gysel, M., Laborde, M., Keller, A., Kim, J., Petzold, A., Onasch, T. B., Lohmann, U., and Mensah, A. A.: Mass spectrometry of refractory black carbon particles from six sources: carbon-cluster and oxygenated ions, Atmos. Chem. Phys., 14, 2591-2603, doi:10.5194/acp-14-2591-2014, 2014.

DeCarlo, P. F., Kimmel, J. R., Trimborn, A., Northway, M. J., Jayne, J. T., Aiken, A. C., Gonin, M., Fuhrer, K., Horvath, T., Docherty, K. S., Worsnop, D. R., and Jimenez, J. L.: Field-deployable, high-resolution, time-of-flight aerosol mass spectrometer, Anal. Chem., 78, 8281-8289, doi:10.1021/ac061249n, 2006.

Drechsler, D. M., Garcia, C., Mehadi, A., Nystrom, M. Propper, R. Rake, D. Takemoto, B., VanCuren, T., Webber, W., Ostro, B., Dodge, D., and Lipsett, M.: Review of the California Ambient Air Quality Standard For Ozone, Vol. I, California Environmental Protection Agency, 2004.

Durbin, T. D., Miller, J. W., Younglove, T., Huai, T., and Cocker, K.: Effects of Fuel Ethanol Content and Volatility on Regulated and Unregulated Exhaust Emissions for the Latest Technology Gasoline Vehicles, Environ. Sci. Technol., 41, 4059-4064, doi:10.1021/es061776o, 2007.

Giechaskiel, B., Ntziachristos, L., Samaras, Z., Scheer, V., Casati, R., and Vogt, R.: Formation potential of vehicle exhaust nucleation mode particles on-road and in the laboratory, Atmos. Environ., 39, 3191-3198, doi:10.1016/j.atmosenv.2005.02.019, 2005.

Gordon, T. D., Presto, A. A., May, A. A., Nguyen, N. T., Lipsky, E. M., Donahue, N. M., Gutierrez, A., Zhang, M., Maddox, C., Rieger, P., Chattopadhyay, S., Maldonado, H., Maricq, M. M., and Robinson, A. L.: Secondary organic aerosol formation exceeds primary particulate matter emissions for lightduty gasoline vehicles, Atmos. Chem. Phys., 14, 4661-4678, doi:10.5194/acp-14-4661-2014, 2014a.

Gordon, T. D., Presto, A. A., Nguyen, N. T., Robertson, W. H., Na, K., Sahay, K. N., Zhang, M., Maddox, C., Rieger, P., Chattopadhyay, S., Maldonado, H., Maricq, M. M., and Robinson, A. L.: Secondary organic aerosol production from diesel vehicle exhaust: impact of aftertreatment, fuel chemistry and driving cycle, Atmos. Chem. Phys., 14, 4643-4659, doi:10.5194/acp-14-46432014, 2014b.

Happonen, M., Lähde, T., Messing, M. E., Sarjovaara, T., Larmi, M., Wallenberg, L. R., Virtanen, A., and Keskinen, J.: The comparison of particle oxidation and surface structure of diesel soot particles between fossil fuel and novel renewable diesel fuel, Fuel, 89, 4008-4013, doi:10.1016/j.fuel.2010.06.006, 2010.
Heeb, N. V., Saxer, C. J., Forss, A. M., and Bruhlmann, S.: Correlation of hydrogen, ammonia and nitrogen monoxide (nitric oxide) emissions of gasoline-fueled Euro-3 passenger cars at transient driving, Atmos. Environ., 40, 3750-3763, doi:10.1016/j.atmosenv.2006.03.002, 2006.

Henze, D. K., Seinfeld, J. H., Ng, N. L., Kroll, J. H., Fu, T.-M., Jacob, D. J., and Heald, C. L.: Global modeling of secondary organic aerosol formation from aromatic hydrocarbons: highvs. low-yield pathways, Atmos. Chem. Phys., 8, 2405-2420, doi:10.5194/acp-8-2405-2008, 2008.

Huffman, J. A., Docherty, K. S., Mohr, C., Cubison, M. J., Ulbrich, I. M., Ziemann, P. J., Onasch, T. B., and Jimenez, J. L.: Chemically-Resolved Volatility Measurements of Organic Aerosol from Different Sources, Environ. Sci. Technol., 43, 5351-5357, doi:10.1021/es803539d, 2009.

Hurley, M. D., Sokolov, O., Wallington, T. J., Takekawa, H., Karasawa, M., Klotz, B., Barnes, I., and Becker, K. H.: Organic aerosol formation during the atmospheric degradation of toluene, Environ. Sci. Technol., 35, 1358-1366, 2001.

Jathar, S. H., Friedman, B., Galang, A. A., Link, M. F., Brophy, P., Volckens, J., Eluri, S., and Farmer, D. K.: Linking Load, Fuel, and Emission Controls to Photochemical Production of Secondary Organic Aerosol from a Diesel Engine, Environ. Sci. Technol., 51, 1377-1386, doi:10.1021/acs.est.6b04602, 2017.

Jayne, J. T., Leard, D. C., Zhang, X., Davidovits, P., Smith, K. A., Kolb, C. E., and Worsnop, D. R.: Development of Aerosol Mass Spectrometer for Size and Composition Analysis of Submicron Particles, Aerosol Sci. Tech., 33, 49-70, 2000.

Johnson, T., Caldow, R., Pöcher, A., Mirme, A., and Kittelson, D. A new electrical mobility particle sizer spectrometer for engine exhaust particle measurements, SAE Technical Papers, 2004-011341, doi:10.4271/2004-01-1341, 2004.

Kang, E., Root, M. J., Toohey, D. W., and Brune, W. H.: Introducing the concept of Potential Aerosol Mass (PAM), Atmos. Chem Phys., 7, 5727-5744, doi:10.5194/acp-7-5727-2007, 2007.

Kang, E., Toohey, D. W., and Brune, W. H.: Dependence of SOA oxidation on organic aerosol mass concentration and $\mathrm{OH}$ exposure: experimental PAM chamber studies, Atmos. Chem. Phys., 11, 1837-1852, doi:10.5194/acp-11-1837-2011, 2011.

Karjalainen, P., Pirjola, L., Heikkilä, J., Lähde, T., Tzamkiozis, T., Ntziachristos, L., Keskinen, J., and Rönkkö, T.: Exhaust particles of modern gasoline vehicles: A laboratory and an on-road study, Atmos. Environ., 97, 262-270, doi:10.1016/j.atmosenv.2014.08.025, 2014.

Karjalainen, P., Timonen, H., Saukko, E., Kuuluvainen, H., Saarikoski, S., Aakko-Saksa, P., Murtonen, T., Bloss, M., Dal Maso, M., Simonen, P., Ahlberg, E., Svenningsson, B., Brune, W. H., Hillamo, R., Keskinen, J., and Rönkkö, T.: Time-resolved characterization of primary particle emissions and secondary particle formation from a modern gasoline passenger car, Atmos. Chem. Phys., 16, 8559-8570, doi:10.5194/acp-16-8559-2016, 2016.

Karlsson, H., Gåste, J., and Åsman, P.: Regulated and non-regulated emissions from Euro 4 alternative fuel vehicles, SAE technical paper 2008-01-1770, Society of Automotive Engineers: Society of Automotive Engineers: Warrendale, PA, USA, 2008.

Keskinen, J. and Rönkkö, T.: Can Real-World Diesel Exhaust Particle Size Distribution be Reproduced in the Laboratory? A Critical Review, J. Air Waste Manage., 60, 1245-1255, 2010. 
Keuken, M. P., Moerman, M., Voogt, M., Blom, M., Weijers, E. P., Röckmann, T., and Dusek, U.: Source contributions to $\mathrm{PM}_{2.5}$ and $\mathrm{PM}_{10}$ at an urban background and a street location, Atmos. Environ., 71, 26-35, doi:10.1016/j.atmosenv.2013.01.032, 2013.

Kiendler-Scharr, A., Wildt, J., Dal Maso, M., Hohaus, T., Kleist, E., Mentel, T. F., Tillmann, R., Uerlings, R., Schurr, U., and Wahner, A.: New particle formation in forests inhibited by isoprene emissions, Nature, 461, 381-384, doi:10.1038/nature08292, 2009.

Kittelson, D. B.: Engines and nanoparticles: A review, J. Aerosol Sci., 29, 575-588, doi:10.1016/S0021-8502(97)10037-4, 1998.

Kroll Jesse, H., Smith Jared, D., Worsnop Douglas, R., and Wilson Kevin, R.: Characterisation of lightly oxidised organic aerosol formed from the photochemical aging of diesel exhaust particles, Environ. Chem., 9, 211-220, 2012.

Lähde, T., Rönkko, T., Virtanen, A., Solla, A., Kytö, M., Söderström, C., and Keskinen, J.: Dependence between nonvolatile nucleation mode particle and soot number concentrations in an EGR equipped heavy-duty Diesel engine exhaust, Environ. Sci. Technol., 44, 3175-3180, doi:10.1021/es903428y, 2010.

Lambe, A. T., Ahern, A. T., Williams, L. R., Slowik, J. G., Wong, J. P. S., Abbatt, J. P. D., Brune, W. H., Ng, N. L., Wright, J. P., Croasdale, D. R., Worsnop, D. R., Davidovits, P., and Onasch, T. B.: Characterization of aerosol photooxidation flow reactors: heterogeneous oxidation, secondary organic aerosol formation and cloud condensation nuclei activity measurements, Atmos. Meas. Tech., 4, 445-461, doi:10.5194/amt-4-445-2011, 2011.

Lambe, A. T., Chhabra, P. S., Onasch, T. B., Brune, W. H., Hunter, J. F., Kroll, J. H., Cummings, M. J., Brogan, J. F., Parmar, Y., Worsnop, D. R., Kolb, C. E., and Davidovits, P.: Effect of oxidant concentration, exposure time, and seed particles on secondary organic aerosol chemical composition and yield, Atmos. Chem. Phys., 15, 3063-3075, doi:10.5194/acp-15-3063-2015, 2015.

Li, W., Perry, K. L., Narayanaswamy, K., Kim, C. H., and Najt, P.: Passive Ammonia SCR System for Lean-burn SIDI Engines, SAE International Journal of Fuels and Lubricants, 3, 99-106, doi:10.4271/2010-01-0366, 2010.

Liati, A., Schreiber, D., Dimopoulos Eggenschwiler, P., Arroyo Rojas Dasilva, Y., and Spiteri, A. C.: Electron microscopic characterization of soot particulate matter emitted by modern direct injection gasoline engines, Combust. Flame, 166, 307-315, doi:10.1016/j.combustflame.2016.01.031, 2016.

Lipari, F.: Determination of individual hydrocarbons in automobile exhaust from gasoline-, methanol- and variable-fueled vehicles, J. Chromatogr., 503, 51-68, 1990.

Mao, J., Ren, X., Brune, W. H., Olson, J. R., Crawford, J. H., Fried, A., Huey, L. G., Cohen, R. C., Heikes, B., Singh, H. B., Blake, D. R., Sachse, G. W., Diskin, G. S., Hall, S. R., and Shetter, R. E.: Airborne measurement of $\mathrm{OH}$ reactivity during INTEX-B, Atmos. Chem. Phys., 9, 163-173, doi:10.5194/acp-9-163-2009, 2009.

Maricq, M.: Chemical characterization of particulate emissions from diesel engines: A review, J. Aerosol Sci., 38, 1079-1118, doi:10.1016/j.jaerosci.2007.08.001, 2007.

Maricq, M., Szente, J. J., and Jahr, K.: The Impact of Ethanol Fuel Blends on PM Emissions from a LightDuty GDI Vehicle, Aerosol Sci. Tech., 46, 576-583, doi:10.1080/02786826.2011.648780, 2012.

Matthew, B. M., Middlebrook, A. M., and Onasch, T. B.: Collection Efficiencies in an Aerodyne Aerosol Mass Spec- trometer as a Function of Particle Phase for Laboratory Generated Aerosols, Aerosol Sci. Tech., 42, 884-898, doi:10.1080/02786820802356797, 2008.

Mejia-Centeno, I., Martinez-Hernandez, A., and Fuentes, G. A.: Effect of low-sulfur fuels upon $\mathrm{NH}_{3}$ and $\mathrm{N}_{2} \mathrm{O}$ emission during operation of commercial three-way catalytic converters, Top Catal., 42-43, 381-385, doi:10.1007/s11244-007-0210-2, 2007.

Mirme, A.: Electrical aerosol spectrometry, PhD thesis, University of Tartu, Tartu, Estonia, 1994.

Ng, N. L., Kroll, J. H., Chan, A. W. H., Chhabra, P. S., Flagan, R. C., and Seinfeld, J. H.: Secondary organic aerosol formation from $m$-xylene, toluene, and benzene, Atmos. Chem. Phys., 7, 3909-3922, doi:10.5194/acp-7-3909-2007, 2007.

Nordin, E. Z., Eriksson, A. C., Roldin, P., Nilsson, P. T., Carlsson, J. E., Kajos, M. K., Hellén, H., Wittbom, C., Rissler, J., Löndahl, J., Swietlicki, E., Svenningsson, B., Bohgard, M., Kulmala, M., Hallquist, M., and Pagels, J. H.: Secondary organic aerosol formation from idling gasoline passenger vehicle emissions investigated in a smog chamber, Atmos. Chem. Phys., 13, 6101-6116, doi:10.5194/acp-13-6101-2013, 2013.

Ntziachristos, L., Giechaskiel, B., Pistikopoulos, P., Samaras, Z., Mathis, U., Mohr, M., Ristimäki, J., Keskinen, J., Mikkanen, P., Casati, R., Scheer, V., and Vogt, R.: Performance evaluation of a novel sampling and measurement system for exhaust particlecharacterization, SAE Technical Paper Series, 2004-01-1439, doi:10.4271/2004-01-1439, 2004.

Odum, J. R., Hoffmann, T., Bowman, F., Collins, D., Flagan, R. C., and Seinfeld, J. H.: Gas/particle partitioning and secondary organic aerosol yields, Environ. Sci. Technol., 30, 2580-2585, doi:10.1021/Es950943+, 1996.

Onasch, T. B., Trimborn, A., Fortner, E. C., Jayne, J. T., Kok, G. L., and Williams, L. R., Davidovits, P., and Worsnop, D. R.: Soot Particle Aerosol Mass Spectrometer: Development, Validation, and Initial Application, Aerosol Sci. Tech., 46, 804-817, doi:10.1080/02786826.2012.663948, 2012.

Ortega, A. M., Day, D. A., Cubison, M. J., Brune, W. H., Bon, D., de Gouw, J. A., and Jimenez, J. L.: Secondary organic aerosol formation and primary organic aerosol oxidation from biomass-burning smoke in a flow reactor during FLAME-3, Atmos. Chem. Phys., 13, 11551-11571, doi:10.5194/acp-1311551-2013, 2013.

Owen, K. and Coley, T.: Automotive Fuels Reference Book, Society of Automotive Engineers, Warrendale, ISBN 1-56091-589-7, 1995.

Palm, B. B., Campuzano-Jost, P., Ortega, A. M., Day, D. A., Kaser, L., Jud, W., Karl, T., Hansel, A., Hunter, J. F., Cross, E. S., Kroll, J. H., Peng, Z., Brune, W. H., and Jimenez, J. L.: In situ secondary organic aerosol formation from ambient pine forest air using an oxidation flow reactor, Atmos. Chem. Phys., 16, 2943 2970, doi:10.5194/acp-16-2943-2016, 2016.

Peng, Z., Day, D. A., Stark, H., Li, R., Lee-Taylor, J., Palm, B. B., Brune, W. H., and Jimenez, J. L.: $\mathrm{HO}_{x}$ radical chemistry in oxidation flow reactors with low-pressure mercury lamps systematically examined by modeling, Atmos. Meas. Tech., 8, 4863-4890, doi:10.5194/amt-8-4863-2015, 2015.

Peng, Z., Day, D. A., Ortega, A. M., Palm, B. B., Hu, W., Stark, H., Li, R., Tsigaridis, K., Brune, W. H., and Jimenez, J. L.: Non-OH chemistry in oxidation flow reactors for the study of atmospheric 
chemistry systematically examined by modeling, Atmos. Chem. Phys., 16, 4283-4305, doi:10.5194/acp-16-4283-2016, 2016.

Pirjola, L., Karjalainen, P., Heikkila, J., Saari, S., Tzamkiozis, T., Ntziachristos, L., Kulmala, K., Keskinen, J., and Ronkko, T.: Effects of fresh lubricant oils on particle emissions emitted by a modern gasoline direct injection passenger car, Environ. Sci. Technol., 49, 3644-3652, doi:10.1021/es505109u, 2015.

Platt, S. M., El Haddad, I., Zardini, A. A., Clairotte, M., Astorga, C., Wolf, R., Slowik, J. G., Temime-Roussel, B., Marchand, N., Ježek, I., Drinovec, L., Mocnik, G., Möhler, O., Richter, R., Barmet, P., Bianchi, F., Baltensperger, U., and Prévôt, A. S. H.: Secondary organic aerosol formation from gasoline vehicle emissions in a new mobile environmental reaction chamber, Atmos. Chem. Phys., 13, 9141-9158, doi:10.5194/acp-13-91412013, 2013.

Presto, A. A., Gordon, T. D., and Robinson, A. L.: Primary to secondary organic aerosol: evolution of organic emissions from mobile combustion sources, Atmos. Chem. Phys., 14, 5015-5036, doi:10.5194/acp-14-5015-2014, 2014.

Robinson, A. L., Donahue, N. M., Shrivastava, M. K., Weitkamp, E. A., Sage, A. M., Grieshop, A. P., Lane, T. E., Pierce, J. R., and Pandis, S. N.: Rethinking organic aerosols: semivolatile emissions and photochemical aging, Science, 315, 1259-1262, doi:10.1126/science.1133061, 2007.

Rönkkö, T., Virtanen, A., Vaaraslahti, K., Keskinen, J., Pirjola, L., and Lappi, M.: Effect of dilution conditions and driving parameters on nucleation mode particles in diesel exhaust: laboratory and on-road study, Atmos. Environ., 40, 2893-2901, doi:10.1016/j.atmosenv.2006.01.002, 2006.

Rönkkö, T., Lähde, T., Heikkila, J., Pirjola, L., Bauschke, U., Arnold, F., Schlager, H., Rothe, D., Yli-Ojanperä, J., and Keskinen, J.: Effects of gaseous sulphuric acid on diesel exhaust nanoparticle formation and characteristics, Environ. Sci. Technol., 47, 11882-11889, doi:10.1021/es402354y, 2013.

Rönkkö, T., Pirjola, L., Ntziachristos, L., Heikkilä, J., Karjalainen, P., Hillamo, R., and Keskinen, J.: Vehicle engines produce exhaust nanoparticles even when not fueled, Environmental Science and Technology, 48, 2043-2050, doi:10.1021/es405687m, 2014.

Sandström-Dahl, C., Erlandsson, L., Gasste, J., and Lindgren, M.: Measurement Methodologies for Hydrocarbons, Ethanol and Aldehyde Emissions from Ethanol Fuelled Vehicles, SAE International Journal of Fuels and Lubricants, 3, 453-466, doi:10.4271/2010-01-1557, 2010.

Sato, K., Hatakeyama, S., and Imamura, T.: Secondary organic aerosol formation during the photooxidation of toluene: $\mathrm{NO}_{x}$ dependence of chemical composition, J. Phys. Chem. A, 111, 9796-9808, doi:10.1021/jp071419f, 2007.

Sato, K., Nakao, S., Clark, C. H., Qi, L., and Cocker III, D. R.: Secondary organic aerosol formation from the photooxidation of isoprene, 1,3-butadiene, and 2,3-dimethyl-1,3-butadiene under high NOx conditions, Atmos. Chem. Phys., 11, 7301-7317, doi:10.5194/acp-11-7301-2011, 2011

Sato, K., Takami, A., Kato, Y., Seta, T., Fujitani, Y., Hikida, T., Shimono, A., and Imamura, T.: AMS and LC/MS analyses of SOA from the photooxidation of benzene and 1,3,5-trimethylbenzene in the presence of $\mathrm{NO}_{x}$ : effects of chemical structure on SOA aging, Atmos. Chem. Phys., 12, 4667-4682, doi:10.5194/acp-124667-2012, 2012.
Song, C., Na, K., Warren, B., Malloy, Q., and Cocker, D. R.: Secondary organic aerosol formation from the photooxidation of $\mathrm{p}$ and o-xylene, Environ. Sci. Technol., 41, 7403-7408, 2007.

Suarez-Bertoa, R., Zardini, A. A., Platt, S. M., Hellebust, S., Pieber, S. M., El Haddad, I., Temime-Roussel, B., Baltensperger, U., Marchand, N., Prévôt, A. S. H., and Astorga, C.: Primary emissions and secondary organic aerosol formation from the exhaust of a flex-fuel (ethanol) vehicle, Atmos. Environ., 117, 200-211, doi:10.1016/j.atmosenv.2015.07.006, 2015.

Timonen, H., Carbone, S., Aurela, M., Saarnio, K., Saarikoski, S., Ng, N. L., Canagaratna, M. R., Kulmala, M., Kerminen, V.M., Worsnop, D. R., and Hillamo, R.: Characteristics, sources and water-solubility of ambient submicron organic aerosol in springtime in Helsinki, Finland, J. Aerosol Sci., 56, 61-77, doi:10.1016/j.jaerosci.2012.06.005, 2013.

Tkacik, D. S., Presto, A. A., Donahue, N. M., and Robinson, A. L.: Secondary organic aerosol formation from intermediate-volatility organic compounds: cyclic, linear, and branched alkanes, Environ. Sci. Technol., 46, 8773-8781, doi:10.1021/es301112c, 2012

Tkacik, D. S., Lambe, A. T., Jathar, S., Li, X., Presto, A. A., Zhao, Y., Blake, D., Meinardi, S., Jayne, J. T., Croteau, P. L., and Robinson, A. L.: Secondary organic aerosol formation from in-use motor vehicle emissions using a potential aerosol mass reactor, Environ. Sci. Technol., 48, 11235-11242, doi:10.1021/es502239v, 2014.

Turner, D., Xu, H., Cracknell, R. F., Natarajan, V., and Chen, X.: Combustion performance of bio-ethanol at various blend ratios in a gasoline direct injection engine, Fuel, 90, 1999-2006, doi:10.1016/j.fuel.2010.12.025, 2011.

Westerholm, R., Ahlvik, P., and Karlsson, H. L.: An exhaust characterization study based on regulated and unregulated tailpipe and evaporative emissions from bi-fuel and flexi-fuel light-duty passenger cars fuelled by petrol (E5), bioethanol (E70, E85) and biogas tested at ambient temperatures of +22 and $7^{\circ} \mathrm{C}$, Final report to the Swedish Road Administration, 2008.

Willis, M. D., Lee, A. K. Y., Onasch, T. B., Fortner, E. C., Williams, L. R., Lambe, A. T., Worsnop, D. R., and Abbatt, J. P. D.: Collection efficiency of the soot-particle aerosol mass spectrometer (SP-AMS) for internally mixed particulate black carbon, Atmos. Meas. Tech., 7, 4507-4516, doi:10.5194/amt-7-4507-2014, 2014.

Volkamer, R., Ziemann, P. J., and Molina, M. J.: Secondary Organic Aerosol Formation from Acetylene $\left(\mathrm{C}_{2} \mathrm{H}_{2}\right)$ : seed effect on SOA yields due to organic photochemistry in the aerosol aqueous phase, Atmos. Chem. Phys., 9, 1907-1928, doi:10.5194/acp9-1907-2009, 2009.

Yanowitz, J., Knoll, K., Kemper, J., Luecke, J., and McCormick, R. L.: Impact of adaptation on flex-fuel vehicle emissions when fueled with E40, Environ Sci. Technol., 47, 2990-2997, doi:10.1021/es304552b, 2013.

Zhang, X., Cappa, C. D., Jathar, S. H., McVay, R. C., Ensberg, J. J., Kleeman, M. J., and Seinfeld, J. H.: Influence of vapor wall loss in laboratory chambers on yields of secondary organic aerosol, $\mathrm{P}$. Natl. Acad. Sci. USA, 111, 5802-5807, 2014. 